\title{
Ethnicizing \\ Employability \\ Governing the Unemployed in Labour Market Projects in Sweden
}

\author{
Viktor Vesterberg
}

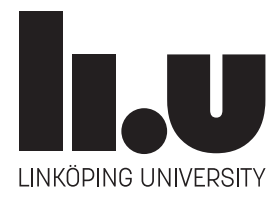

Department of Social- and Welfare studies

Linköping University, Sweden

Linköping 2016 
(C) Viktor Vesterberg, 2016

Printed by LiU-Tryck, Linköping, Sweden, 2016

ISBN 978-91-7685-781-6

ISSN 0282-9800 


\section{CONTENTS}

ACKNOWLEDGEMENTS .............................................................. 5

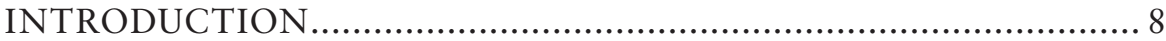

Positioning the thesis: migration, welfare, labour and unemployment ......12

Globalization and migration ......................................................... 13

The European Union and neoliberalism ........................................... 14

Labour, unemployment and migration in Sweden ................................ 15

The European Social Fund ................................................................. 17

Previous research on the governmentality of employability and learning.. 20

Previous research on ethnicized employability.....................................24

ANALYTICAL APPROACH, THEORY, AND METHOD ................ 28

Governmentality as analytical approach ...........................................2 28

Governing, ethnicity, and race ........................................................... 36

Research questions and aim of the thesis........................................... 39

Reflections on methods and methodology ........................................ 40

The research process and empirical material ...................................... 43

Ethical considerations and reflections.................................................48

SUMMARY OF THE ARTICLES ......................................... 51

CONCLUDING DISCUSSION ................................................. 59

SAMMANFATTNING ........................................................ 63

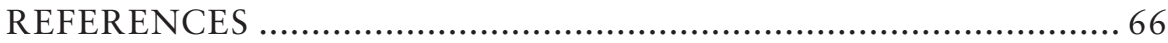

ARTICLE I:

Learning to be Swedish ..................................................................... 79

ARTICLE II:

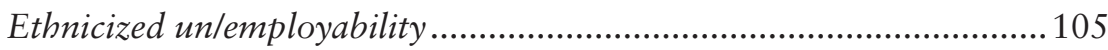

ARTICLE III:

Exploring misery discourses ............................................................ 133

ARTICLE IV:

Rationalities of exclusionary inclusion ............................................ 161 



\section{ACKNOWLEDGEMENTS}

This dissertation ${ }^{1}$ would not have been written without the co-operation and inspiration from other people. First and foremost, my two supervisors Magnus Dahlstedt and Åsa-Karin Engstrand, who have been tireless in their support and encouragement during the $\mathrm{PhD}$ process.

Magnus - you rock! Ever since you tutored me on the master's thesis, you have been a source of inspiration and given me valuable insights about everything and nothing, high and low, in academia as well as outside. I have always felt that your door is open and that you are happy to answer questions, discuss worries, help sorting thoughts or just chat about heavy metal for a while. Your feeling for when to step in as a supervisor and offer a steady hand and when to leave me wandering the world of books in search for insights have been most balanced. Your endless reading, commenting and re-reading of numerous drafts have been truly helpful. Finally, we got our thumbs out and started to write about job coaching together - something that we have been discussing for half a decade.

Åsa-Karin, thank you for a good co-operation already in TIA, we had fun making analysis and writing reports on everything from the Lisbon strategy to job coaching together. Thanks also because you made it possible for me to go to Capri to the graduate student conference on critical management studies, which ultimately led to the first article published in the thesis. Thanks also for being a very challenging supervisor: your questions of the character 'Why is this interesting?' 'Why is your analytical perspective better than any other?' have certainly been anxiety-provoking, but more importantly, they have forced me to never stop reflecting on why I do what I do, the way I do it.

$\mathrm{PhD}$-colleagues from all generations at REMESO, Caroline Tovatt, Martin Qvist, Sara Ahlstedt, Christophe Foultier, Indre Genelyte, Karin Krifors, Jennie K Larsson, Nedžad Mešić, Xolani Tshabalala, Julia Willén, Olav Nygård and Andrey Tibajev - everyone in their own unique way, are amazing people and colleagues. Thanks for everything from in-

1 This work was supported by the Swedish research Council for Health, Working Life and Welfare [Grant number $2006-1524]$. 
spiration and friendship to parties and intellectual discussions. Without you, doing PhD studies would not have been such a rewarding experience.

Andreas Fejes - besides being an excellent opponent on the 60 percent seminar, delivering insightful comments, you have also given me the opportunity to write about employability in the Studentlitteratur anthology - thanks! Thanks also to Anders Neergaard and Julia Peralta for valuable and insightful comments on the 60 percent seminar.

Kerstin Jacobsson - without Learning to be employable, I would not have written this thesis! Thank you for your extensive reading and your very important comments in the final stages of the dissertation. Thanks also to Marinette Fogde and Kenneth Peterson, for carefully reading and commenting the manuscript for the 90 percent seminar. Thanks to all the REMESO colleagues who have commented on and read the drafts in different stages.

Special thanks also to Anders Neergaard, Nedžad Mešić, Aleksandra Ålund, Carl-Ulrik Schierup, René León Rosales and the rest of the 'Reimagineering the nation seminar' for valuable comments on the last chapter of the dissertation. Extra thanks to Sasha, Calle and Anders for the opportunity to be a part of this anthology.

Kenneth Peterson, thank you for numerous discussions on everything from TV series to how to understand 'technologies of the self'. I also want to thank you for being the 'Foucault man' on the SKA program, which actually inspired me to use the analytical perspective I have done in this thesis. Further, you and Stefan Jonsson acted as final readers of the thesis and gave valuable comments which improved the final version of the thesis - a huge thanks to both of you for your efforts. At this point I also want to thank John Revington for careful proof-reading and language editing.

Anita Andersson, a friend through thick and thin. Your roles and areas of inspiration have been many, as a mentor in all kinds of issues, as an experienced and wise teacher and as a comrade one can discuss anything and everything with. You have guided and supported me to handle course responsibility and all sorts of educational issues. Maria Arvidsson, with your pranks and jokes, your humor as well as wisdom have made the time at Bomull much more fun. Mathias Martinsson, a wise colleague who I often have consulted on educational issues. Thanks for adventures 
in Finspång and for generously inviting me to nice evenings with good food and wine, play, funny hats and late nights. Eva Bolander, thank you for stimulating and fun co-operation at the SKA program. Thanks to Judith Lind and the rest of the 'UK4-gang' in Linköping, which for many years has been a rewarding context to teach in. A big thanks goes to Eva Rehnholm and Gunilla Bygdén for your professional and helpful administrative support.

I also want to thank my mother and father, Ann and Ove, and my brother Mattias for always being supportive and encouraging me when it comes to the quite unexpected, but life-changing, choice to sell the chainsaws and start studying at the university.

Last but certainly not least, a big thanks to Rebecca Odin, my partner, first and foremost for the amazing person you are, but also for all the nights when we discussed various drafts, your zealous and thorough proof-reading and wise comments.

Norrköping, 20I6-03-29 


\section{INTRODUCTION}

Alarming reports concerning unemployment and social exclusion among migrants and ethnicized groups have become part and parcel of everyday news coverage and political debates in Sweden. In contemporary political debates, unemployment is often understood as a lack of employability (Garsten and Jacobsson 2004), hence unemployment among ethnicized target groups becomes an issue of their un/employability. This dissertation analyzes constructions of the problem of un/employability among ethnicized target groups in Sweden. The aim is to interrogate how this problem is made intelligible, how it is constructed and made solvable. More specifically, the dissertation focuses on how un/employability is ethnicized and problematized within labour market projects co-funded by the Swedish European Social Fund (ESF). ${ }^{2}$ Two quotes from the ESF's webpage may illustrate how issues of un/employability are problematized in terms of ethnicity:

Many Somalis are excluded from working life and are dependent on welfare from society. [...] The goal of the project is to create work and self-sufficiency among Somalis. [...] The project shall motivate and realize the work strategy among Somalis. In this way, the project will break with a passivating way of life, and increase the Somalis activity on the labour market (Swedish ESF council 2016a). ${ }^{3}$

Approximately $80 \%$ of the Roma population are unemployed. Many Roma interrupt their primary or secondary education [...]. Evaluations show that there is a need for specific training courses for the Roma, their often negative experiences of studies means that they need extra time and resources. The project aim is that unemployed Roma through tailored sewed training courses reaches employment or further studies (Swedish ESF Council 2016b).

Sweden is a society in which public discourse frowns upon explicit racism and xenophobia - official institutions as well as many individuals mirror themselves in values such as social justice and equal rights for

2 ESF will be discussed in more detail later.

3 All translations are my own unless otherwise stated. 
all (Pred 2000; Schierup and Allund 20II). This is also the case for the ESF, with main slogan 'jobs and new opportunities for all' (Swedish ESF Council 20I6c), indicating a will to provide opportunities for everybody to be included in society. In addition, Sweden has an international reputation of having developed generous and progressive immigration policies (Schierup, Hansen, and Castles 2006).

Nevertheless, the rate of unemployment among people not born in Sweden is much higher than for those born in Sweden (Behtoui 2006; Ministry of Employment 20II; OECD 20I5). Activities for integrating migrants and creating social inclusion have increasingly focused on enhancing the employability of the migrant target groups (Dahlstedt 2009a; Diedrich and Styhre 2013). A prerequisite for practices engaged in the social inclusion of migrants through measures of enhanced employability is to construct the targeted group as being - at least in principle and at their present stage - unemployable and excluded and hence in need of specific policies of re-education and transformation. This is the rationality which will be further explored in this thesis.

Using a governmentality perspective, this thesis focuses on how constructions of un/employability is being ethnicized - i.e. how ethnicity is mobilized in practices that are engaged in social inclusion and employability. A governmentality perspective is particularly useful when analyzing taken-for-granted truths and claims about specific issues (Fejes 2006; Foucault I99I). Thus, it is crucial to empirically investigate, as well as theoretically elaborate, how the everyday governing of the unemployed is made possible through discourses of ethnicized un/employability. The analytical approach of this thesis theorizes how the position of unemployed ethnicized groups is problematized, and how ethnicized un/employability is constructed as a way of making the targeted subjects governable. The thesis thus contributes to the study of governmentalities of employability. Further, it shows how constructions of ethnic difference interact with convictions concerning the labour market positions of certain groups and how this underlies specific governmental interventions.

Sweden is famous for its 'universal welfare politics' (Esping-Andersen I990). This universalism also includes policies concerned with the inclusion of migrants as integration measures generally should target the whole population and measures specifically targeting migrants should be limited in time after their arrival in Sweden. Despite the explicit ambition 
not to target specific groups or immigrants as a group, after their initial time spent in Sweden (Skr. 2008/09: 24), two groups of migrants and/or national minorities stand out. In the first article of this thesis, Roma and Somali are identified as explicitly problematized in relation to the labour market as well as to society in general.

These groups have very different histories in relation to Sweden, yet they are both deemed as exceptions to the more general politics of integration. Somalis on the one hand form a relatively new group of immigrants to Sweden. The longstanding, ongoing civil war that has plagued Somalia since the beginning of the I990s is the main reason for migrations from Somalia to Sweden. The number of people living in Sweden who were born in Somalia has been steadily increasing since 2000. Somalis are one of the biggest groups of new arrivals in Sweden as well as being a participant group in the ESF-funded labour market projects that target unemployed migrants (Thörnquist 20II). One government report (Carlson, Magnusson and Rönnqvist 20I2) states that the rate of employment among Somalis in Sweden in 20 IO was 2 I percent. The most prominent explanatory factor highlighted in the report is poor or undocumented education. The report concludes that Somalis are one of the groups with the least successful inclusion on the labour market. The construction of Somalis as unemployable and ethnicized Others will be further developed in article two in this thesis. The concepts of Others and Othering is inspired by Said (I979) and his work on Orientalism. From a Western perspective the 'Orient' is embedded in historical colonial discourses, and is constructed as being opposite to the progressive, modern 'West'. The inhabitants of the Orient - the Others - have been, and continue to be, constructed as lazy, unreliable, and backward (Hall I992; Said 1979). I use the terms Others and Othering in order to define how ethnicized Otherness is constructed and problematized in relation to the norms of the 'West'.

For the Roma, being a targeted group is nothing new. The history of the Roma in Sweden goes back approximately 500 years. Roma have been subject to abuse and numerous horrors as well as well-intentioned governmental interventions throughout history. This is also the case outside Sweden. The European Union Agency for Fundamental Rights (FRA 20I6) conducted an interview survey with Roma in eleven European Union countries and the results were disturbing. The socioeconomic condi- 
tions for the Roma are generally worse than for the non-Roma European population. Less than one third of the interviewed Roma stated that they had employment and 90 percent of the Roma population are said to live in households with an income below the national poverty line.

An official report by the Swedish government (SOU 20IO: 55 ) states that a majority of Roma are unemployed or are struggling to avoid misery by recycling bottles, polishing shoes, selling smuggled cigarettes, or begging. The same report announces that almost nine out of ten Roma in Slovakia are unemployed; that half of the Roma population in Spain lacks steady and legal employment; and that between 50 and 80 percent of the Roma in the Czech Republic are unemployed. In most European countries the level of employment for Roma is about 20 percent below the majority of the population. In Sweden, the Roma population has the status of a national minority, although they are a heterogeneous group that migrated to Sweden in several periods from the I6th century onwards. Thus, using the term migrant when analyzing constructions of Roma, is quite problematic. Some Roma may have migrated to Sweden, but far from all Roma have any experience of migration. Regarding the ESF projects analyzed in this thesis, it tends to be unclear whether they are targeting Roma who have migrated to Sweden or not. Therefore, I use the terms ethnicized (target) groups when referring to Roma, and/or migrants when referring to groups or persons who are targeted due to their experience of migration. Article three in this thesis further analyzes how Roma are positioned in, and constructed through, various discourses of misery.

It is clear that Roma and Somalis are two groups constructed as particularly problematic regarding both their social and labour market integration. These groups are targeted in spite of the general or universal social and integration politics considered normal in Sweden. As will be shown in this thesis, these two groups are both constructed and problematized through discourses of ethnicized Otherness.

ESF also funds projects that specifically target these groups (Thörnquist 20II). Both Roma and Somalis are constructed as excluded from the labour market and thus in need of inclusion through measures of employability. This is the main reason for examining projects targeting Roma and Somalis in this thesis. The rationality that constructs target groups as unemployable and excluded in order to become a rational tar- 
get for practices of inclusion, is analyzed further in article four in this thesis.

Although the articles of this thesis mainly focus on local and everyday practices, they relate to wider discourses on migration, welfare, labour, and unemployment. This thesis analyzes how un/employability is constructed through ethnicized discourses on initiatives that are engaged in combatting social exclusion and promoting inclusion through employability measures. In this work, I analyze the problematization of ethnicized target groups, how the problem of ethnicized un/employability is made intelligible and thus making the targeted subjects governable, within the particular setting of the Swedish ESF. In what follows I will situate this setting within a wider horizon, showing the more general patterns it may disclose.

\section{Positioning the thesis: migration, welfare, labour and unemployment}

Employability as a way to strengthen inclusion has been promoted by international institutions such as the Organisation for Economic Co-operation and Development (OECD), the EU and the United Nations (UN). ESF projects targeting people with a 'foreign background' ${ }^{4}$ are also part of inclusion and labour politics, and the 'work strategy' promoted broadly in Swedish politics (Junestav 2004). Therefore, I will briefly discuss how this thesis relates to the concepts of social inclusion and exclusion. In recent years the discourse of inclusion has become more intertwined with 'the work strategy' in which participation in the labour market is seen as crucial for being included in society (Larsson 2015). In an EU discourse, social inclusion generally refers to the efforts to make citizens employable by preparing them for participation in the labour market (de la Porte and Jacobsson 2012). The twin concepts of social inclusion and exclusion have been pivotal in the EU's social policy since the I990s. At the same time, they have been two of the most frequently used concepts

4 'Foreign background' is a term frequently used by ESF. Statistics Sweden's definition of a person with a foreign background is someone born abroad or born in Sweden with two parents born abroad (Statistics Sweden 2016). 
in the social sciences, with various meanings in different countries. Thus, social inclusion/exclusion is both an analytical and a political concept (Schierup, Krifors and Slavnic 2015). For the purposes of this thesis, I will focus on what is being done in the name of social inclusion, and what rationalities underpin the practices engaged in the social inclusion of ethnicized groups. The following section discusses issues relevant to this thesis, starting on a global scale and then moving on to European Union (EU) and national discourses.

\section{Globalization and migration}

First, the issues addressed in this thesis should be related to economic, political and discursive processes often associated with globalization. The specific practices of employability which target unemployed ethnicized groups, and which are analyzed in this thesis, are related to global discourses. These global discourses are always interpreted and practised locally, and as they are influenced by the particular histories and traditions of the place where they are practised, there is a 'dialectic of the global and the local' (Miller and Rose 2008: 96). Globalization is often analyzed as a 'neoliberal economic growth strategy' that includes de-regulation, privatization, and labour market flexibilization, as advocated by international agencies such as the World Bank, the International Monetary Fund (IMF), and the World Trade Organization (WTO) (Vij 2007:I).

Schram (2007) argues that a globalized world needs new kinds of subjects. As he argues, national citizens are in need of reformulating their sense of self to suit this emerging new world. In this globalized world order, the role of the nation state may have changed, but the importance of the nation state has not disappeared. As argued by Hindess (2005: 242), territorial boundaries still 'remain at the heart of the emerging global order'. The regime of nation states continues to structure the world in fundamental ways, and the 'national order of things' (Malkki I997) contributes to the view of migrants as strangers, as not belonging to the 'imagined community' of the nation (Anderson 2006).

It follows from this that the measures of inclusion and employability targeted at people with a 'foreign background' has a necessary postulate - international migration. The inclusion of migrants is inevitably related to international migration (Anderson 2013) and these issues has been at 
the centre of attention for politicians and researchers as one of the most crucial of our times - times that have been called 'the age of migration' (Castles and Miller 2009; Dahlstedt and Neergaard 201 5). Migration, however, is not a recent phenomenon - human history, in Sweden as well as elsewhere, is a history of mobility and movement (Sassen I999; Svanberg and Tydén I992).

\section{The European Union and neoliberalism}

In the European Union, immigration had become a key political issue by the turn of the millennium. European countries have a demand for highskilled workers such as managers, IT workers, researchers, and experts in medicine. This has led to privileged rules of entry for certain professionals in many European countries. At the same time, there is a demand for low-skilled workers in businesses such as cleaning, housework, health services, and construction. These low-skilled migrant workers do not benefit from any privileged rules of entry but are instead often recruited from the ranks of undocumented migrants and asylum seekers. They have a weak legal status and are targets for discrimination and social exclusion (Schierup et al. 2006). In times of crisis and rising unemployment, these groups of vulnerable migrant workers are among the hardest hit (Castles, Booth and Wallace I984), not least in neoliberal regimes where competition and market-oriented policies are prominent in guiding politics (Schierup et al. 2006; Standing 20I I).

It has often been argued that the EU in particular and 'the West' in general made a significant turn towards neoliberal politics during the I980s and I990s. Hansen and Hager describe how EU policymakers took advantage of the 'neoliberal atmosphere' of the I980s by creating a 'neoliberal European policy consensus' (Hansen and Hager 2010: 62).

However, there is a long history of market-oriented policies in the EU. Walters and Haahr (2005) argue that such policies have been crucial ever since the founding of the European communities. For instance, German neoliberals, sometimes called Ordoliberals, have had a great influence on European economic policy in the post-war era. The German neoliberals advocated that the whole of society should be organized with the free market as a principle. They wanted a 'state under the supervision of the market rather than a market supervised by the state', as Foucault 
(2007a: I I6) puts it. According to the Ordoliberals, competition is to be seen as the main principle of the market, and hence of society as a whole, since society should be organized as a market. However, competition is not seen as a spontaneous and natural phenomenon. Instead, the right conditions for competition need to be carefully constructed by active policymaking. A concrete example of this is how the EU allows large companies to operate (the downside of capitalist competition is its tendency to create monopolies), as long as they do not abuse their market position; they must act as if they were operating in a competitive market - competition may not be distorted (Walters and Haahr 2005). Neoliberalism, in this sense, should therefore not be understood as laissez-faire politics but rather as permanent vigilance, activity, and intervention on behalf of the state, with the objective of supporting the market and creating and maintaining competition (Foucault 2007a).

Although market-oriented policies promoting competition and growth have been crucial in the EU for a long time, they have changed over time. Up until the I980s, these policies were embedded in social democratic discourses which focused on welfare and social rights, but from the I 980 os neoliberalism was boosted, radicalized, and implemented more thoroughly (Hansen and Hager 20I0).

The most concrete outcome of such market-oriented reasoning in European policymaking is perhaps the enormous effort devoted to the construction of a single, common European market. This huge project also involves attempts to construct a European people, sharing a particular 'European identity' (Hansen and Hager 2010: 60).

\section{Labour, unemployment and migration in Sweden}

In Sweden, unemployment first arose as a kind of socio-political problem of broader concern in the latter half of the I 9 th century (Ulmestig 2007). Prior to industrialization, unemployment was illegal, and vagrants, as the unemployed were called then, would be arrested, and if they were capable of productive work they were put into forced labour (Beronius I994). However, as industrialization gathered momentum and the labour market, in a more contemporary form, began to take shape, the view of the unemployed began to change. Idleness or unemployment were no longer understood as solely a lack of individual character. Politicians started to 
see structural causes for unemployment and thus tried to combat the social problems of unemployment at a more societal level, rather than just disciplining the individual (Ulmestig 2007). The remedies and treatment of the poor and the unemployed underwent a shift from 'alms or arrestment' to an understanding of unemployment as a social problem, to be handled politically rather than through charity and policing. In tandem with this process, a more systematic differentiation and classification was developed in order to distinguish the 'real poor' from those deemed as lazy and morally inferior - those not wanting to work. These differentiations and classifications led to more refined systems of controlling the poor (Beronius I994). There was a concern from politicians and other established members of society that the high rates of poverty and unemployment brought about by industrialization and capitalism would eventually lead to a variety of ills which would disturb the peaceful society. Such disturbances include social unrest, drunkenness, criminality, idleness, vagrancy, and - in the worst scenario - revolution (Ulmestig 2007). This shows that the problem of unemployment was not only seen as a problem of economics, but also of society, dealing with morality and social order. Poverty and unemployment have always been, and still are, issues that involve aspects of moral concern for citizens (cf. Davidsson 2OI 5 ).

In the post-war period of the I950s and I960s unemployment in Sweden was low and labour market politics were characterized by optimism. The main problem to tackle was not unemployment, but rather a labour shortage, which gave rise to labour immigration. During the I970s an increasing proportion of effort and resources were concentrated on those who had problems adapting to the needs of the labour market (Petersson 2009). This 'golden age' began to look less golden with rising unemployment and the international economic downturn of the I970s. When the economy recovered in the I980s, a more market-oriented discourse gained a foothold in Sweden (Berglund and Schedin 2009; Boréus I994).

The economic and financial crisis of the I990s is often described as a period that accelerated the change towards more neoliberal politics in Sweden. This acceleration increased again after I995, when Sweden joined the European Union (Larsson, Letell and Thörn 2012). In I990, unemployment was below two percent and there were more jobs 
available than there were unemployed. Within two years, more than ten percent of the jobs had disappeared. For a long time, unemployment was high, frequently fluctuating between I 2 and I 4 percent. Migrants, particularly those deemed as physically and culturally distant, were hit hard by this 'socially brutal transformation' (Pred 2000: I44) of Swedish society (SOU 2000:3; Vogel, Hjerm and Johansson 2002). Hence, this reshaping of global capitalist labour markets captures, in conspicuous ways, how racism and discrimination operate in the socioeconomic landscape of contemporary Sweden.

With the rise of popular racism and xenophobia during the economic crises of the I990s, Sweden's self-image as a moral role-model was severely damaged (Pred 2000; Schierup and Ålund 20I I). Since the crises of the I990s, approximately one third of the labour force has had loose connections with the labour market, working in atypical jobs and temporary employment, a development that is not only applicable to migrants. For instance people with disabilities and young people with low education were particularly exposed to the effects of the crisis (Peralta 2006). The crises of the I990s marked the beginning of an ongoing shift in Swedish politics from a universalist welfare regime to a workfare regime, with substantial elements of neoliberal rationalities, such as a strong political focus on un/employability rather than on unemployment (Dahlstedt $2009 \mathrm{~b}$ ). As mentioned, this shift in Swedish politics was boosted when Sweden joined the European Union in I 995 (Jacobsson 2004).

\section{The European Social Fund}

The empirical scope of this thesis is the ESF: one of the EU's means to combat the social exclusion of, and discrimination against, vulnerable groups. Therefore, a short background and history of the ESF is needed.

The ESF is one of two EU structural funds. The other structural fund is called the European Regional Development Fund (ERDF) and gives financial support mainly to strengthen infrastructure and to create jobs. The ESF, on the other hand, supports projects engaged in 'promoting labour market integration of unemployed and disadvantaged populations, primarily through support for training activities' (Swedish ESF Council 20I6d). The ESF's goal is thus to produce a competent and employable population. 
The ESF's history goes back to the foundation of the European Coal and Steel Community (ECSC) in I95 r. The main ambition of the ECSC was to ensure that the coal and steel industries were managed collectively. With the war in recent memory, the coal and steel industries were of special interest since they provided key raw material for warfare. A forerunner of the ESF was born out of the ECSC: the ECSC Fund for the Retraining and Resettlement of Workers. The goal of this fund was to help workers in the coal and steel industries to upgrade their skills and to keep pace with industrial developments, or to search for work in other industrial sectors (Hale 2007).

A few years later, in 1957, the European Economic Community (EEC) was founded through the Treaty of Rome. The ESCS fund followed and became the ESF. The ESF was part of the vision for Europe from the start of the EEC, and was engaged in improving jobs, promoting employment, and encouraging increased mobility and flexibility among workers (Hale 2007). In Article I 23 of the Treaty of Rome, the goals of the ESF were established, stating that:

$\ldots$ in order to improve opportunities of employment of workers in the Common Market and thus contribute to raising the standard of living, a European Social Fund shall hereby be established [...]; it shall have the task of promoting within the Community employment facilities and the geographical and occupational mobility of workers.

In the early years of the ESF, the main focus was on compensating for job losses. In the I950s and I960s, unemployment was low in the EEC and mainly concentrated in southern Italy. Therefore, Italians were the main beneficiaries of the fund in this period. Many received funding to be retrained for other occupations, or to be resettled in other geographical locations. As a result, many Italians went to work in the Belgian mines of Wallonia (Hale 2007). Thus, one important objective of the fund was to encourage an increased mobility of European workers - i.e. to promote free movement of labour rather than social justice (Walters and Haahr 2005).

What about the ESF in Sweden? The ESF in Sweden has hitherto co-financed over 90000 projects involving more than one million participants. During the programme period studied in this thesis, 2007-2013, the total budget for the ESF (in the whole of the EU) was SEK 750 bil- 
lion. Of this budget, the ESF in Sweden received SEK 6.2 billion (Swedish ESF Council 2013). Although this is a substantial figure, it is only a small part of the overall budget financing Swedish labour market politics. In 20I 5, the Swedish Ministry of Employment, which is responsible for issues of ethnic integration, equality, and discrimination, had a total budget of approximately SEK 85 billion (Ministry of Employment 20I 5 ) These figures make visible the scope of the efforts being made trying to tackle the social and political problems of unemployment and exclusion among people with a 'foreign background'. This money is spent on employing personnel and experts to work with these matters, and to find ways of preventing and combatting the problems of unemployment and social exclusion among the target groups.

When applying for project funding from the ESF, there is a 'tick-box' for each of the target groups. One such target group is 'Unemployed people with a foreign background'. This illustrates the fund's explicit ambitions to tackle the problem of unemployment among immigrants. In addition to the numerous projects co-funded by the Swedish ESF, they have initiated and co-funded two different thematic groups specialising in these issues. During the programme period $2000-2006$, the national Thematic Network on Asylum and Integration (2016) generated policy-relevant knowledge and advocated good practice derived from integration projects. The programme period $2007-2013$ had its own similar actor financed by the ESF - the Thematic Group on Inclusion (20I2) which was devoted to achieving effective dissemination of knowledge at the policy level through the analysis of ESF-funded projects targeting unemployed people with a 'foreign background'. My interest in analyzing these ESF projects arose from being engaged with the Thematic Group on Inclusion (TIA) as an analyst in 2009 - 20IO. My work in TIA is discussed in more detail later on.

Projects co-funded by the ESF are important to examine regarding how ethnicized target groups are made employable because the ESF is a major channel for disseminating and implementing EU policies to member states and attempting to influence how social and labour politics are carried out (Jacobsson 2004). In addition, the ESF claims to support 'innovative and experimental methods of working' (Swedish ESF Council 2009: 7) in order to reach its goal of social inclusion through enhanced employability - making the fund's projects a kind of laboratory for de- 
veloping techniques to make ethnicized groups employable. This indicates a self-image of ESF as being a kind of spearhead when it comes to labour market integration activities.

\section{Previous research on the governmentality of employability and learning}

This section describes how my study relates to previous research in the field of governmentality studies, with a particular focus on employability, learning and ethnicity, and how these concepts relate to each other.

I present research that I have been inspired by, that has led me to do the kind of analysis I do, and the research I have read during the process of writing this thesis. This has been an ongoing process during which I have searched for relevant research about the issues I have been studying. I limit my overview to governmentality studies focusing on employability and lifelong learning, and the studies of what I have called 'ethnicized employability' - these two being the core areas of the thesis. ${ }^{5}$ As the articles comprising this thesis also contain sections of previous research relevant to each of them, I have deliberately condensed this section to a set of overarching theoretical and conceptual assumptions.

Since the I990s, employability-oriented labour market policies have been widely advocated by powerful and international organisations such as the EU, the OECD and the UN (McQuaid and Lindsay 2005). This policy usage of employability has been examined in parallel by several researchers. The journal Urban Studies (No. 2, 2005) previously devoted a special issue to the concept of employability. Also the journal Ephemera recently published a special issue dedicated to critically discussing the increasing concern about employability (Chertkovskaya, Watt, Tramer and Spoelstra 20I3). Employers' and governmental institutions' understanding of employability is often based on individuality, being concerned with individuals' skills and characteristics (McQuaid and Lindsay 2005).

My interest in the study of employability arose from reading the anthology Learning to be Employable (Garsten and Jacobsson 2004). In

5 How I use governmentality as an analytical approach is elaborated later. 
this anthology a wide range of questions relating to employability and the production of good citizens is explored from analytical perspectives inspired by Foucault. The authors discuss how the question of unemployment and poverty has shifted its focus and is no longer seen as a systemic issue to be solved collectively via welfare state, Keynesian politics.

This demand-side politics was widespread in Western welfare states throughout the I950s and I960s, not least in Europe. However, during the unemployment crisis of the I970s, consensus gradually shifted into a more supply-side oriented labour market politics. The authors argue that since the I990s we have witnessed yet another shift of focus in labour market politics - namely from unemployed/employed to unemployable/ employable (Garsten and Jacobsson 2004). This shift renders unemployment intelligible as more of an individual problem - an unemployable individual is seen to be lacking the skills and characteristics desired by employers. The powerful discourse on responsibilization discussed by Rose (I999a) can be helpful in order to understand this individualization of un/employment and un/employability. Responsibilization indicates a norm for the citizens of contemporary Western societies to be responsible for their own security and welfare - including preventing the risk of unemployment through acquiring adequate job-skills - and to become employable.

A key study within the field of governmentality studies on employability has been carried out by Dean (I995). Although he studied actions which targeted unemployed people in Australia in the I990s, he provides important insights into how a governmentality perspective can be useful in the study of unemployment. He argues that measures targeting the unemployed seek to reform the capacities and attributes of the unemployed and to reshape their attitudes and aspirations. Here, a clear link becomes visible to the employers' common definition of employability as the individual skills and characteristics, as mentioned above. With the use of techniques to counteract low self-esteem, isolation, poor morale, and low motivation, these practices also address personal effects of unemployment.

Dean (I998) has also discussed the labour market measures targeting the unemployed in terms of a reworking of the ethical life of the unemployed citizens. He focuses his analysis on the ethical character of governing the unemployed - especially those understood to be 'disad- 
vantaged' or 'targeted groups'. In order to grasp the hybrid nature of practices governing the unemployed, Dean (I998) focuses his analysis on the direction and self-direction of the conduct of both those who exercise authority (employability experts), and those over whom authority is exercised (unemployed, targeted groups). Dean concludes that governing the unemployed is directed towards the unemployed becoming active citizens and jobseekers, rather than being passively unemployed. He relates this to Foucault's discussion on American neoliberalism, and the concept of human capital stemming from the Chicago School of Economics and its version of the figure homo economicus.

The figure of homo economicus as a sort of ideal subject in contemporary Western societies is further elaborated by Hamann (2009). He argues that neoliberal governmentality seeks to create conditions for creating the homo economicus, a subject guided by self-interest, making rational choices based on a cost-benefit rationality and market principles. This particular formation of subjectivity is produced in neoliberal discourses permeating almost all spheres of our daily life.

Similar analyses have been carried out by Miller and Rose (2008) who discuss the contemporary Western government of unemployment as operating through the refiguring of the unemployed. This involves the reconstruction of being unemployed to becoming active jobseekers who are constantly searching for employment and upgrading their skills to become employable. Active jobseekers in contemporary Western societies are governed towards adopting an entrepreneurial and flexible state of mind in order to promote themselves.

The governmentality of employability has also been studied in Sweden. Fogde (2009) has investigated how university students in Sweden are targeted for career guidance given by trade unions in order to enhance their employability. Through a governmentality approach, Fogde investigates how 'the jobseeker', as a subject, is positioned within discourse. The ideal jobseeker is constructed as skilled in communication, sellable, and flexible, and is fostered with techniques such as $\mathrm{CV}$-writing and preparing for job interviews. As will be shown in this thesis, similar techniques are also deployed when measures of employability are targeting unemployed migrants and ethnicized groups.

Employability has also become a widely spread concern for the Swedish education system. Carlbaum (20I I, 20I2) has analyzed Swed- 
ish education policy showing how Swedish schools have become increasingly focused on employability and generating a skilled work force. She concludes that the education system produces 'good citizens' in the shape of subjects capable of sustaining business and growth. This ideal good citizen, in the shape of an entrepreneur, is gendered as well as ethnicized. Carlbaum (20II) argues that the male entrepreneur is privileged, white, and middle class. However, in the last decades, 'migrant-businesses' and 'ethnic entrepreneurship' have gained an increasing interest in politics as well as in research (Klinthäll and Urban 2014; Pripp I998). Entrepreneurship as a way of tackling unemployment is also explicitly advocated in the ESF projects analyzed in this thesis.

As discussed above, a political focus on employability entails individuals taking more responsibility for making themselves employable (Garsten and Jacobsson 2004). Using discourse analysis focusing on the concept of governmentality, Fejes (2010) further analyzes who is construed as being responsible for citizens' employability. He concludes that in the last decades, individual citizens have been made responsible for their own employability, while the state and employers are seen more as enabling actors who create possibilities for citizens to carry out their lifelong responsibility to be employable.

The practices of employability targeting unemployed ethnicized groups are often played out in what can be called learning practices. Two of the articles in this thesis are published in journals which focus specifically on lifelong learning and adult education. Lifelong learning is also a topic that has been thoroughly analyzed using governmentality approaches (cf. Fejes and Nicoll 2008; Masschelein, Simons, Bröckling and Pongratz 2007).

In a learning society (Masschelein et al. 2007), in which lifelong learning has become a central value, citizens are construed as specific subjects understanding themselves as being subjects for whom learning is a natural part of life - they are fostered to become lifelong learners (Simons and Masschelein 2007). At least from the I980s, the EU has been actively engaged in constructing Europe as a place 'occupied by lifelong learners' (Popkewitz, Olsson and Petersson 2007: I7). For those wishing to be and to stay employable, continuous learning is an integral part of their working life in a flexible labour market. Equally, learning 
to become employable is a mandatory part of being unemployed in the learning society (Tuschling and Engemann 2007).

Job training, the learning of specific skills deemed relevant in working life, becomes part of the everyday practices of lifelong learning targeting unemployed (Fogde 2008). Being an active jobseeker involves, as Fogde (2008) argues, acquiring skills on how to write an adequate CV, and how to behave during job interviews. Here, the active jobseeker is contrasted to the passive unemployed (Dean I998).

The construction of Europe as a place inhabited by lifelong learners becomes highly interesting in the light of international migration and the integration of migrants. As shown in this thesis, migrants and other ethnicized groups tend to be constructed as 'problematic learners' (Brine 2006) in labour market projects engaged in social inclusion and employability. Although lifelong learning is a widely investigated topic from a governmentality perspective, ethnicized constructions of learning subjects and employability seem not to be as widely investigated. In the following section the focus is on governmentality studies which analyze employability measures targeting ethnicized groups.

\section{Previous research on ethnicized employability}

Anna Lundstedt's (2005) dissertation Vit governmentalitet: 'Invandrarkvinnor' och textilhantverk - en diskursanalys [White governmentality: 'Immigrant women' and textile handicrafts - a discourse analysis] is primarily focused on social textile projects in the r99os targeting women of 'foreign backgrounds'. The study shows how discourses on multiculturalism and heteronormativity materialize in labour market projects. Furthermore, it appears that stereotypes about the Other are reflected in the projects' selection of target groups as well as working methods, creating clear distinctions between 'Swedishness' and 'immigrant status' (Lundstedt 2005), a demarcation also highlighted in the articles of this thesis.

Wright Nielsen's (2009) thesis Viljen til att frigöre: En undersögelse af empowerment $i$ praksis [The will to liberate: An investigation of empowerment in practice] focuses on a labour market project co-funded by the ESF targeting women with a 'foreign background'. The project was part of the ESF's programme period $2000-2006$. The study focuses 
on how empowerment is constructed in the project and, in turn, what these empowerment practices are supposed to achieve. In the ESF project studied, empowerment appear as a 'will to liberate' these women from their culture, considered to be a deviation from the norms of Swedishness (Wright Nielsen 2009). Similar rationalities permeate some of the projects analyzed in the articles in this thesis. Although Lundstedt's and Wright Nielsen's dissertations are close to this thesis in their analytical perspective and empirical cases, there are also differences, as the construction of un/employability is not the primarily focus of the analysis in either of these two studies.

Guo (2013) analyzes discourses of integration as practice and policy in Canadian programmes targeting adult migrants. The results of Guo's study show that migrants are involved in unpaid work placements to complement their 'lack of Canadian experience'. The study further indicates a strong focus on 'presentability and employability' in the programs analyzed. These results show similarities and differences when compared to the results of this thesis. Similar to the case of the ESF projects in Sweden is that migrants in the programmes studied in Canada are encouraged to adopt certain values and cultural norms. One interesting result in Guo's (2013) study is that migrants are encouraged to anglicize their names. Although this might also occur in Sweden (taking 'Swedish sounding' names), it has not been found while studying the ESF projects.

Andersson and Guo (2009) focus on the learning of adult migrants. They adopt a governmentality approach, without explicitly focusing on learning for employability. They focus on how migrants are governed through techniques of 'prior learning assessment and recognition' (PLAR). In contrast to this thesis, which analyzes projects focusing on long-term unemployed migrants, the practices analyzed by Andersson and Guo (2009) target 'immigrant professionals'. However, there are similarities with the results of this thesis as PLAR operates as a 'system of governing through excluding, normalizing and dividing' (Andersson and Guo 2009: 435). According to Andersson and Guo (2009), the prior working experience and learning of migrants are devalued, and are constructed through PLAR as not being transferable or recognizable, and thus deemed different, deficient, and inferior.

Bonfanti (2014) analyzes Sweden's reform of labour migration in 2008 , focusing on the 'truths', norms, and values embedded in the poli- 
cies analyzed. The results suggest that Swedish immigration policies are imbued with neoliberal discourses which construct the value of the migrants as relating primarily to their contribution to Swedish economic growth. This result is in line with the analysis of ESF policies in this thesis, which also stress the importance of enabling migrants to contribute to gross domestic product (GDP), and which construct migrants as 'untapped resources'.

van Baar (20I2) analyzes how Roma in Slovakia are made governable through socioeconomic problematization, a focus similar to the article in this thesis analyzing how Roma are constructed through, and positioned in, discourses of misery. van Baar (20I2) argues that programmes of labour market activation and social inclusion targeting Roma, tend to increase rather than decrease the social exclusion of the Roma because there is a focus on reducing their 'dependency' on social benefits. This result resembles what I refer to in the thesis as a 'rationality of exclusionary inclusion'. Through such rationality, the subjects who are to be included are initially constructed as Others, and positioned as excluded from normality.

The studies presented above are a selection that have inspired and informed my research and analytical perspective. There is no doubt that employability and unemployment are widely investigated and are an established field of research in its own. However, the question of how un/ employability is ethnicized seems not to be equally researched. Quantitatively oriented research dedicated to measuring the disadvantages of ethnicized groups in working life is more common (e.g., Carmichael and Woods 2000; Conley and Topa 2002; Leslie and Drinkwater I998). Since the situation of migrants and ethnic minorities in general - and their place in the labour market in particular - is a political issue of great concern in many countries, quantitative research illustrating the disadvantaged situation of migrants is most important and useful, not least from a policymaking perspective. However, such research tends to conceptualize ethnicity as something that pre-exists as a measurable variable, instead of focusing on how ethnicity is used and produced. In relation to such a conceptualisation, this thesis theorizes how un/employability is ethnicized and how the position of ethnicized unemployed subjects are problematized and made governable. I would argue that the development of this particular analytical perspective contributes to the 
study of governmentalities of employability and is useful for analyzing the construction of ethnicized un/employability as well the governing of unemployed migrants and ethnicized Others. 


\section{ANALYTICAL APPROACH, \\ THEORY, AND METHOD}

Theory and method cannot easily be separated in discourse-oriented research (Howarth 2000; Mills I997). Governmentality is an analytical approach, providing flexible and open-ended analytical tools rather than a coherent method or theory. These tools can be adapted to, and made compatible with, many different methods, and can be used in many different fields of research (Rose, O’Malley and Valverde 2009). However, for the sake of clarity, I shall discuss the issues of theory and method separately, at least partially. The actual and concrete methods used for creating analyzable empirical material for each of the articles in this thesis are presented separately from the more general reflections on methods and methodology. I think it is important to see methods in more than one way - both as concrete methods for creating empirical material, and as methodology for analyzing that empirical material.

The section is structured according to the following: Firstly, the analytical approach used in this thesis is presented. Secondly, the concepts of ethnicity and race, and the way they are used are discussed. Thirdly, the aims and research questions of the thesis are presented. Fourthly, the methods and methodology are discussed, followed by a presentation of the concrete methods used in the research process and for the construction of empirical material. Fifthly, the section ends with reflections on ethical concerns.

\section{Governmentality as analytical approach}

The analytical point of departure for this thesis is based on a Foucauldian understanding of governmentality (Dean 20I0; Rose I999a; Rose I999b), which draws attention to the 'rationalities of government' (Foucault 2007b) and the 'art of governing' (Foucault I99I). Rose (I999a) argues that governing operates according to certain rationalities which seek to construct specific ways of understanding the task at hand. Dean (20I0) argues that rationalities of governing relate to specific forms of truth which seek to render particular problems and issues governable. Analyzing rationalities from a governmentality perspective thus focuses on more or less systematic ways of reasoning that involve certain tech- 
niques deployed for reaching what is the goal of governing (Rose, I999a). In this way, a governmentality approach broadens the conventional understanding of government, opening up for analyzing the ways in which the targets of governing are actively shaped in accordance with certain norms, and made governable throughout various societal domains (Ettlinger 20II).

Foucault offers neither a fixed analytical perspective nor a coherent theoretical framework for analysis. Rather, his concepts and analytical strategies vary over different periods. However, this does not mean that he abandoned or totally changed his thoughts, concepts, and perspectives. Rather, he developed, refined, and elaborated on them, using different terminologies (O'Farrell 2005). This resulted in a 'toolbox' of concepts, picked up and used in numerous fields of research and in a range of disciplines.

In what has been referred to as Foucault's 'archaeological period', the concept of discourse is prominent and defined as autonomous systems of statements, structured through certain rules. In what has been referred to as his 'genealogical period', there is a shift of focus and the main analytical concept is power/knowledge rather than discourse (Howarth 2000). In Foucault's later work, his focus of analysis shifts again. Now, ethics and the way in which individuals constitute themselves as moral subjects is highlighted. How individuals are, and have been, constituted as subjects remained a concern for Foucault throughout his career.

[W] hat has been the goal of my work during the last twenty years [...] has been to create a history of the different modes by which, in our culture, human beings are made subjects (Foucault 2000: 326).

In line with Foucault (2000), I use the concept of subject in the double sense of individual subjectivity, in terms of identity and self-knowledge, as well as subjection of the individual, in terms of how the subjects are governed and constructed by others as well by themselves. It is such an understanding of the subject and the formation of subjectivity that informs the analysis in this thesis.

Foucault first uses the term governmentality in his Collège de France lectures of 1978 and I979. As an analytical approach, governmentality is used to analyze how societal discourses and everyday practices pro- 
duce each other. Here, governmentality can be understood as the governing of mentalities as well as the mentalities of governing, communicated through discourses and practised through techniques of power (Ettlinger 2OII).

The study of governmentality has grown in recent decades and has become a field of its own (Walters 20I2). Governmentality studies have been conducted in a range of disciplines, investigating a wide variety of empirical domains and phenomena. Nevertheless, such studies share a common interest in the specific analytical approach, seeking to analyze 'the art of government' (Bröckling, Krasmann and Lemke 20II: Iof). This does not only refer to the government of the state, but to government as an 'activity that consists in governing people's conduct' (Foucault 2007a: 3 I 8 ) in a broad sense. Analyzing the art of government with a focus on the 'conduct of conduct' may involve how subjects are being governed by expertise as well as the governing of oneself according to certain norms. An analysis of the 'technologies of the self' focus on how subjects constitute themselves as responsible beings through for instance self-reflection, self-regulation and technologies of empowerment (Cruikshank I999; Rose I999a).

In using a governmentality perspective, then, I seek to capture how practices of inclusion and employability seek to steer and foster subjects, encouraging them to govern themselves (cf. Bröckling et al. 20I I). The understanding of government, as used in the thesis, provides the analysis of power with a new dimension - recognizing the close relationships between forms of knowledge and techniques of power.

When adopting a governmentality approach, I understand all governing as corresponding with knowledge about what or who should be governed. Here, the relationship between power and knowledge is crucial. The exercise of power shall, in this sense, be understood as decentralized and productive, making the face of power more benign than that of a repressive sovereign. However, this does not imply that the exercise of power is infrequent, but rather diverse and outspread. This in turn enables increased governability through regulating, sanctioning and normalizing human behaviour (Hultqvist and Petersson I995). In line with this understanding, the ESF projects are analyzed as practices which deploy techniques of normalization. The projects are imbued by discourses on inclusion constructing 'the normal' as well as 'the excluded'. Those 
positioned as excluded are constructed as deviant and thus made governable (Popkewitz and Lindblad 2000).

The concept of truth is important in understanding the relationship between power and knowledge. Truth can be understood as a product of society, around which there is a constant battle. Societies, in different times and places, produce their own 'regimes of truth', which are circulated in systems of power that sustain and expand those regimes of truth. The regimes of truth determine what is accepted as legitimate knowledge in a given society, and privileges those who are able to say what counts as true in a specific situation (Foucault I980). In my understanding, relationships of power and knowledge draw upon, alter, and constitute truths.

This, in turn, relates to what Foucault (I980) refers to as the politics of truth. The focus here is not on the conventional dichotomy of true or false. Instead of focusing on whether a certain utterance really is true or false, an analysis of the politics of truth is concerned with how truthclaims are made by individuals, groups, or institutions, and how power relates to certain claims of truth and knowledge (Bröckling et al. 20I I). In this sense, truth cannot be outside of power and there are constant struggles around what it so be accepted as true and what is to be seen as false (Foucault I980). Being able to say what is accepted as truth thus facilitates successful governing.

In the fourth article in the thesis I use the concept of 'games of truth' (Foucault I997a) as a way of analyzing opposition to dominant discourses in the studied labour market projects. These games of truth are played out as language games in which project participants disturb the governing activities by evoking counter-discourses to what is delivered as a truth by project employees. ${ }^{6}$ Foucault argues that there is 'an entire ethnology of truth-telling to be pursued' (Foucault 20I4: I4). Specific events in the projects are analyzed as 'games of truth' involving disagreements over the meaning and usefulness of participating in labour market projects. Such 'games of truth' concern everyday life in the projects and

6 When I write about project employees as experts or project participants it is not the persons per se (specific individuals) I refer to, or have an interest in analyzing, but rather their specific discursive positions. 
can be studied using ethnographic methods in order to capture governing in practice. Through ethnographies of governmentalities it becomes possible to analyze the power relationships as they are played out (Brady 20I4). In these games of truth, the particular techniques deployed, and the dominant discourses constructed, by project employees are contested by project participants, thus guiding the analysis towards 'specific instances of counter-conduct'; something that studies of governmentality has been criticized for neglecting (Bevir 2010: 425 ).

Governmentality as an analytical approach has proven useful in providing a way of understanding how governing is exercised, specifically in contemporary Western societies. Foucault (2007a) identified this contemporary governing as a neoliberal governmentality, while Rose (I996) uses the concept of 'advanced liberal governing'. 'When I use the term 'advanced liberal society' in this thesis, I refer to a society organized around a central goal of providing measures to facilitate economic markets. Government of social life here is structured around the economic logic of enterprises and competition, and human behaviour is thought of primarily in terms of a calculative economic logic (Rose I999a).

The position of experts plays an important part in contemporary advanced liberal governing when claiming authority to govern through adequate knowledge in different fields of government (Rose I999b). Dean (2007: 35 ) argues that governing through what he calls the 'authority of expertise' is central to the study of governmentality. This form of governing can be described as directing or controlling the conduct of others. In order to steer the conduct of others (and your own), different rationalities and techniques through vast varieties of agencies and authorities are set in action.

Rose (I999b: 2) uses the term 'expertise of subjectivity' when referring to a family of professionals whose task is to classify individual and social problems of various kinds, and to prescribe adequate 'remedies'. Even though these forms of knowledge may have their origin in various sciences of the human psyche, they now concern a range of professionals such as social workers, personnel managers, probation officers, and counsellors. In short, these are professions that claim authority based

7 For the purposes of this thesis, the concepts advanced liberal and neoliberal are used interchangeably. 
on their knowledge and understanding of human subjectivity, and their ability to act upon that knowledge and understanding, or to advise others what to do.

The legitimacy of this expertise does not necessary lie in hierarchies, such as the doctor-patient relationship, or unquestioned specialist training and knowledge. Rather, the legitimacy for this kind of authority of expertise lies in the promise of unleashing the inner capacities of individuals in self-fulfilment, to overcome feelings of victimhood, exclusion, and dependency. The authority of expertise sets out to empower the governed, making them feel free (Dean 2007; cf. Cruikshank I999). Or as Rose (I999a: 4) puts it, 'to govern humans is not to crush their capacity to act, but to acknowledge it and to utilize it for one's own objectives'. One crucial aspect of understanding contemporary governing of humans lies in the value that is given to the concept of freedom. Discourses of freedom have come to define the foundation of what is understood as good in contemporary Western societies (Rose I999a). Hence, contemporary government targets subjects who understand themselves as being free in some sense. Targeted subjects can, more or less successfully, choose to resist the governing they are exposed to. Much of the governing in the studied labour market projects is associated with the goal of producing subjects who understand themselves as free individuals, fostering a view of life as a 'matter of freedom of choice' (Rose r999a: 65). In this way, governing presupposes the freedom of the governed (Rose I999a), and the task for the experts becomes to guide the free will of targeted subjects.

In addition to the 'authority of expertise', Dean (2007:36) introduces the notion of 'ruling with authority' as a form of government based on law. Ruling with authority and governing through the authority of expertise can be understood in relation to the views of power as being productive and/or repressive. Repressive power is often based on law, and is negative and sometimes destructive, whereas productive power is based on norms and knowledge, producing subjectivities. This distinction is not clear-cut and watertight, instead these two forms of governing co-exist and intertwine in different ways.

What then, are the possible flaws and disadvantages in engaging with a governmentality perspective? There has been a criticism that contemporary studies of governmentality are missing out on historicizing aspects 
of the different phenomena that are being investigated. Walters (20I2) argues for the fruitfulness of reconnecting governmentality with genealogy. The 'genealogical sensibility' that Foucault practised in his different empirical studies has in recent years fallen away, leading to a narrow focus on 'a very contemporary temporal horizon' (Walters 2OI 2: III).

Although I do not claim to be making a genealogical study, I try to be sensitive to this criticism. In article three I historicize the problematizations of Roma in Sweden by contrasting contemporary empirical material with a governmental report from the I950s (SOU I956: 43). The kinds of investigations that are being conducted under the umbrella of genealogy vary substantially, hence there is no 'genuine' genealogy. Common to genealogical studies is a will to destabilize the present, to generate an understanding that what we are and how things are in the present are not a given and are not inevitable (Walters 20I2). I use historical empirical material as a way of illustrating the similarities and differences of how the Roma have been problematized in two distinct periods - the I950s and the 20IOs. Such an analytical strategy opens up for problematizing contemporary problematizations of Roma.

There has also been a criticism of governmentality studies for being deterministic and being a 'top-down' style of analysis in which the subject is simply constructed through powerful and dominant discourses (McKee 2009). In using a governmentality perspective, I focus on local practices of governing in labour market projects. This is not to say that practices and discourses that reach beyond the local cannot be touched upon. Rather, it is an ascending style of analysis, starting at the local level, and potentially making it possible to analyze connections to wider discourses (Bröckling et al. 20I I), and making visible the 'dialectic of the global and the local' (Miller and Rose 2008: 96). For instance, the construction of ethnicized subjects in labour market projects relates to the wider discourses of the nation and the nation state, which in turn creates migrants and enables border crossings and international migration.

This criticism of governmentality being deterministic also involves a blindness to resistance in power relationships - a criticism of not seeing power as always being relational, and that power is always accompanied by counter-power and opposition (McKee 2009). In article four, I address this criticism by analyzing opposition in power relationships in an attempt to avoid deterministic tendencies, where the process of 
constructing subjects is only understood from the viewpoints of experts and dominant discourses. Here, the concept of 'games of truth' enables an analysis of how dominant discourses are contested and how counter-conduct is staged. In doing so, I draw upon previous ethnographic fieldwork carried out in ESF projects in 2009 and 2010.

Hörnqvist (2OI2) argues that if the relational character of power is to be taken seriously one needs to recognize that different power positions have different capabilities for successful exercise of authority. In this thesis, I see the experts of employability (i.e. project employees) as acting from an authoritative position, being charged with the possibility of exercising power successfully. However, this is not to imply that power only operates in one direction - where there is power, there is always resistance, and resistance is never 'outside' power, but is rather an intrinsic aspect of any power relationship. Power is only power when exercised on subjects who, as the unemployed project participants, are able to act and counteract in one way or another (Gordon I99I). Power, then, is the plurality of relationships inherent in and that organizes the field within which it operates. Power does not only delimit, demarcate, or restrict, it also constructs the subjects involved in specific relationships (Foucault 2002).

The view that contemporary government is dispersed rather than centralized, and takes place in networks rather than in single bureaucracies, leads to an analysis of 'government as a practice rather than as a set of institutions' (Walters 2012: 65). Thus, from a governmentality perspective, power is not viewed as exercised in a top-down fashion, from a single centre - i.e. the State. When analyzing welfare/workfare politics with a governmentality approach, the focus is not on economic consequences, but rather on governmental rationalities and the 'conduct of conduct' which shape subjectivities through discourses (Vij 2007).

While working with a governmentality approach, I encountered some issues that have required me to consider and reflect on how I employ the analytical approach in relation to my aims and research questions. One issue that appeared as problematic to me concerns the Foucauldian conceptual apparatus. Foucault is not known for always being very stringent and precise with the concepts he developed. Rather, he elaborated and reworked the meaning of his analytical concepts over time and used them in different ways for different purposes. Rabinow and Rose (2003: 
viii) describe Foucault's thinking as 'sometimes contradictory, sometimes reinterpreting texts of the past [...], sometimes suggesting new and untried investigations, sometimes jumping in completely different ways'. This has stimulated me to take Foucault's own encouragement seriously and to use his wide range of concepts as 'little toolboxes, [...] to open them, to use this sentence or that idea as a screwdriver or spanner to short-circuit, discredit or smash systems of power' (Foucault in Patton I979: I I 5). Thus, employing a governmentality approach and Foucauldian analytical concepts does not provide the researcher with a robust theory and a methodology that could function as clear instructions on how to perform analysis. Rather, it encourages innovativeness and independence about how to choose from the available analytical tools, as well as how to use them.

Nevertheless, 'Foucault studies' has in a way grown into a research discipline in itself (Hultqvist and Petersson I995), with gatekeepers, watchdogs, and what Foucault (I98I) himself called 'discourse police', guarding how certain concepts should or should not be used, what the correct interpretation of a specific concept is, and so on. To navigate the tensions between the innovativeness and playfulness encouraged by the 'toolbox approach' and the strictness of 'Foucault studies' has been challenging. I have tried to elaborate on my own ways of choosing and using analytical tools, while at the same time remaining receptive and responsive to the knowledge and norms produced in the field of Foucault studies and governmentality.

In order to make this analytical approach more comprehensible for the analysis of ethnicization, we also need to discuss how the concepts of ethnicity and race can be analyzed and understood from the perspective of governmentality.

\section{Governing, ethnicity, and race}

One important theoretical issue in this thesis concerns the concepts of ethnicity and race. Therefore I will now discuss how these concepts may relate to each other and how they are used in this thesis. I refer to the process of constructing and problematizing ethnicity and race as ethnicization and racialization (cf. Miles and Brown 2003), to emphasize 
that my focus is on how ethnicity and race are constructed and used in specific ways.

There is a growing field of critical race studies focusing on whiteness and racialization in different disciplines and empirical domains, both in Sweden (Hübinette, Hörnfeldt, Farahani and Rosales 2012) and internationally (Delgado and Stefancic 20I0). Pripp (2005) argues that the norms prevailing in the Swedish labour market subordinate certain phenotypic appearances, such as dark skin colour in relation to dominant norms of whiteness. Pripp (2005) further argues that constructions of hierarchical racial differences in Sweden are often understood through discourses of cultural differences, thus relating the problem of integration to the migrants.

A common and widely used distinction between the concepts of race and ethnicity is that race is concerned with biological and genetic features, while ethnicity is concerned with cultural and religious differences. Miles and Brown (2003: 99) make a similar distinction between ethnicization and racialization when they define ethnicization as a 'process by which meaning is attributed to socio-cultural signifiers of human beings'. In relation to this, racialization is understood as a specific modality of ethnicization in which biological and/or somatic features are signified.

However, the distinction between ethnicity and race has been challenged and rethought. Following Gunaratnam (2003), I view ethnicity and race not as two clearly separated concepts, but as constructed through similar and intertwining discourses on difference. As Goldberg (2009: 175) argues, race is not simply a matter of biology and skin colour, but rather a complex set of rationalities regarding how culture is 'tied to colour', how being is tied to body, and how blood is tied to behaviour. In this way, race has become ethnicized, and ethnicity has become racialized (Cohen I999), hence the boundaries between the two are blurred. Goldberg ( I993: 75) uses the term ethnorace to shed light on the overlap and blurring between ethnic and racial constructions. He argues that 'the biological' can be one of many possible criteria for determining ethnicity, and that many social groups spoken about in terms of ethnicity have in the past been identified in terms of race.

In this thesis, for the sake of terminological consistency, I use the term ethnicity rather than race, being aware that they are often synonymous and overlapping for the reasons just mentioned. I analyze how 
ethnicization is made or evoked as an important category in the studied labour market projects. Ethnicization works through constructions of differences in relation to what is understood as normal (cf. Hall I996). In this game of articulating differences (Hall 2000), 'foreignness' positions certain subjects as deviant in relation to a normalized 'national belonging' - i.e. the subject becomes ethnicized (Snajdr 2007). In the everyday practices of labour market projects, ethnicity tends to be constructed in a straightforward and non-problematic way, according to what Brubaker (2006: 9) has called 'ethnic common sense'. In line with this, the main focus of the analysis made in this thesis, is on the common sense constructions of ethnicity in the labour market projects, where unemployed people attending the projects are trying to get their everyday life going, and project employees are trying to help and coach these unemployed people to find jobs. Such activities also contain ethnicization and an exercise of power, positioning the unemployed as Others who are in need of normalizing interventions from experts who shape their subjectivities (Osman 2006).

When analyzing the ESF projects, project employees are seen as experts who, with the power, knowledge, and truth invested in them, are able to determine who constitutes an employable and included subject, and who does not. In the analysis, the authority of expertise and productive power provides a useful analytical starting point. In the analyzed projects, the rationality is that migrants and other ethnicized groups will overcome feelings of exclusion and dependency, and become included and empowered through wage work. This form of governing is concerned with the shaping of the needs, desires, and aspirations of targeted subjects and populations for specific ends (cf. Dean 2007). Here, the intersections between the mentalities of government, truth, knowledge, power, and expertise are central for the analysis.

Clearly, this does not mean that productive power is the only way of governing migrants. Ruling with authority (repressive power) has become conspicuous in the management of migration, for instance at the external borders of the EU, not least considering the recent European 'refugee crisis' (Carrera, Blockmans, Gros and Guild 2015). The EU's 'militarized fight against illegal immigration' (Hansen and Hager 2010: ix), or the repressive, exclusionary, and punitive techniques governing 'illegal' immigration to the USA (Inda 2006), are clearly cases of author- 
itative and violent rule based on force and law. However, I would argue that those migrants who succeed in crossing EU borders and obtaining the status of legal settlers on EU territory are more often the target of productive power and the authority of expertise. Nevertheless, migrants legally or illegally residing in a country are still subjected to the rule of authority, with one example being the threat of deportation (Anderson 2013). Therefore, in the end, how and when a 'legal migrant' is the target of productive or repressive power becomes an empirical question.

My interest is not primarily in understanding what or who, for instance, Roma or Somalis truly are. Instead, I analyze constructions of ethnicity as part of, and similar to, constructions of other dimensions of subjectivities. In analyzing this everyday ethnicization, the notion of 'conduct of conduct' comes to the fore. Experts of employability, i.e. project employees, seek to guide and steer the conduct and self-understanding of the project participants in ways that involve the construction of ethnicities. Project participants are also involved in such activities, either confirming or opposing them. A kind of ethnicizing of the conduct of conduct is what I am analytically trying to grasp. Although the main focus of this thesis is the construction of ethnicity, this does not mean that I turn a blind eye when intersections with other categorizations are evoked in the empirical material. This means that it is crucial to be sensitive when it comes to how ethnicity is constructed in relation to other categorizations.

The analytical approach and theoretical understanding of ethnicity and race elaborated above informs both the research questions and aim of this thesis, which are now presented in more detail.

\section{Research questions and aim of the thesis}

To sum up the considerations above, it is the aim of this thesis to analyze constructions of the problem of un/employability among ethnicized target groups and to interrogate how this problem is made intelligible, how it is worked upon, and how it is made solvable.

In my analytical approach, I seek to problematize the rationalities underpinning the constructions of ethnicized un/employability among target groups who are constructed as being in need of specific interventions for becoming employable, and thus included in the societal community. 
The research questions posed in order to achieve the aim of this thesis are inspired by Dean (1996) and Foucault (1983), with a focus on studying the what, who, why, and how of governing. This set of questions is intertwined with and guides the analytical compass of this thesis - what to look for in the empirical material and the kinds of questions to be asked when conducting the analysis.

What is problematized within the practices that target unemployed ethnicized groups? This question involves analyzing problematizations of the targeted subjects and relates to the problem of ethnicized un/employability.

Who is to be governed? Who are the targeted groups? Who is governing? These questions involves analyzing the discursive positions from where the governing is practised and the positions at which governing is targeted, as well as the relationship of power between these positions.

Why are unemployed ethnicized groups constructed as problematic in relation to the labour market, and understood as being in need of specific interventions? This question involves analyzing problematizations of the targeted subjects in relation to the norms of employability, as well as analyzing the rationalities underpinning such problematizations.

How are the targeted groups to be governed? This question involves analyzing the discourses and governing techniques deployed when fostering employable subjects.

Not all of these questions are answered in all the articles in this thesis, but they are discussed with an emphasis on different aspects that are specific to the aims of each article. Altogether, however, they make up the analytical compass that guides the thesis as a whole. To be able to interrogate these questions one needs specific research methods. Therefore we now shall discuss in further detail the methods and methodology of the thesis.

\section{Reflections on methods and methodology}

When conducting discourse oriented research with a governmentality perspective, it is not always a simple task to draw clear lines between method, methodology, and theory. Methods and theory are intertwined to form a methodological package containing epistemological and onto- 
logical assumptions about the role of language as constructing the social world (Winther-Jörgensen and Phillips 2002).

In the four articles in this thesis, empirical material is analyzed from a specific angle in seeking to illustrate how governing is exercised through problematizations and constructions of ethnicities in relation to un/employability. In each article, specific analytical tools suitable for the aims of that particular analysis have been elaborated on and adopted. In addition to this overarching discussion, each article includes a discussion on the specific methods and methodology used in it.

I start this discussion by distinguishing between method and methodology. Following Silverman (2000) I view method as a specific research technique and methodology as a general approach to research.

When reflecting on methodology, it is important to recognize that knowledge is situated, in the sense that the creation of empirical material is bound to a specific analytical perspective. As discussed above, governmentality as an analytical perspective does not prescribe a distinct set of methods to construct knowledge. Rather, it provides a research perspective, 'an angle of view' and a specific orientation to examine the phenomena being studied (Bröckling et al. 20 I I: I 5). Therefore, it is necessary to reflect upon how, and with what methods the empirical material of this thesis has been selected and created.

In labour market projects which target unemployed ethnicized groups, the employability experts (i.e. project employees) construct certain truths about how social inclusion is to be achieved through enhanced employability, why participants are unemployed, and what their needs are. As shown in article four, these truths may differ from those put forward by the targeted subjects (i.e. the project participants). This thesis does not aspire to tell the truth, but rather to analyze claims about telling the truth. The employee has, in many respects, a more forceful power-position in relation to the project participants. Employees are experts in their field of work; they have an institutional and professional base supporting their knowledge and their know-how in the field. They have access to public domains, such as the media, where they may claim their truths. The position of the employee is also embedded in and governed by political discourses such as national labour market policy and ESF policy. The capability and power to create the truth about the project is therefore closer at hand for the employees than for the unemployed 
project participants. However, as shown in article four, analyzing empirical material from ethnographic fieldwork, this does not mean that the project participants are totally silenced or subdued.

When it comes to the more technical aspects - such as the actual methods used when creating and selecting empirical material - one can say that I am mainly analyzing discourses. From a governmentality perspective, and by being engaged in analyzing how governing takes place in discourses, it is not particularly useful to hierarchize one type of empirical material, such as interview transcripts or governmental reports, as being truer or better than any other - different types of material can be analyzed with the same analytical tools (Börjesson and Palmblad 2007). All of the different types of empirical material analyzed in this thesis produce claims to truth, construct reality, and render visible attempts to govern.

Although analyzed with the same analytical tools, analyzable material created using ethnographic methods can have its advantages. In this way, the everyday activities of governing, the 'games of truth' and the construction of subjectivities can be captured in a way that recognizes resistance and counter-conduct. When focusing solely on archive material, such as the ESF project data bank, resistance in relationships of power is hard to analyze (cf. Brady 20I4). Ethnographic material can enable a way of tackling one of the more common criticisms of governmentality studies - namely that of being deterministic, of seeing subjectivities solely as being produced from above and failing to recognize resistance and counter-conduct, all of which are intrinsic in any relationship of power (Bröckling et al. 20I I).

When conducting interviews from a discourse-oriented governmentality perspective, the interview is of course not viewed as a reflection of an objective reality, but rather as a locally situated spoken discourse which is produced through the collaboration between interviewer and interviewee (Alvesson 2003). I have viewed all the empirical material, the transcribed interviews, ethnographic field notes, policy documents and project descriptions, as discourses. But I also see them as being able to tell something about the different aspects of the governmentalities that were analyzed, where the ethnographic material enables the interruptions and disturbances of governing to be captured (Bröckling et al. 20I I) through 'games of truth', and where dominant discourses constructed by experts 
can be destabilized by those who are targeted by the activities of governing.

The strategy used when selecting empirical cases has similarities with purposive sampling, which Silverman (2000) describes as a strategy allowing the researcher to choose cases which illustrate, in a good way, the phenomena being analyzed. I have selected empirical material in which I believe the object of study would most likely occur.

The phenomenon analyzed in this thesis is the ethnicization of un/ employability, and the empirical field selected to analyze this phenomenon is the group of labour market projects co-funded by the ESF which targets unemployed migrants and Roma. The main reason for choosing this particular case is that it contains empirical material which focuses on issues of employability and social inclusion of ethnicized groups.

\section{The research process and empirical material}

This brings us to the research process with regards to creating the empirical material that is analyzed in this dissertation. Here, I will first provide a background of how the topic of the ESF-financed labour market project became my empirical focus, and then I will describe the research process of creating empirical material for each article. The processes of gathering empirical material and conducting the analysis are more intertwined - moving back and forth, formulating and rejecting ideas, and writing and rewriting the analysis - than it may appear in the following discussion.

In 2009-20I0 I was employed in the Thematic Group on Inclusion (TIA) which was a project within REMESO, Linköping University. TIA was co-financed by the ESF with the task of producing knowledge about ways of working with migrant integration and social inclusion in the ESF projects, and how those ways of working could create equal opportunities in working life (Thematic Group on Inclusion 2013). During the work in TIA, several scientific reports were published based on ethnographic fieldwork carried out in ESF projects throughout Sweden. Article number four in this dissertation is based on the ethnographic fieldwork I carried out during my time in TIA. This fieldwork is elaborated on in more detail below. In TIA, a mapping of all ESF projects that were granted funding during 2008 was carried out (Engstrand, Andersson and Ves- 
terberg 2010). The mapping showed that nearly half of the projects were preoccupied with the integration of migrants, indicating that ethnic and migrant integration is an important issue for the ESF. The three most frequently used approaches for enhancing the employability of unemployed ethnicized target groups in these projects were education, work placement, and job coaching, usually in combination (Engstrand et al. 2010). Further, analysis from TIA has shown that unemployed Roma and Somalis were groups of particular interest for ESF projects (Thörnquist 20II). This information generated a curiosity to explore these projects further, which eventually led to the research in this thesis.

In three of the articles of this study, the analyzed empirical material consists mainly of projects self-descriptions. These self-descriptions were written by people working in the projects and sent to the Swedish ESF for publication in an online project bank.

Thus, my material for the first article, Learning to be Swedish, consists of project descriptions from the Swedish ESF online project bank for the programme period $2007-2013$. The projects were selected by searching for certain keywords. The words that I used to search the project bank were: foreign, immigrant, and refugee. ${ }^{8}$ This search resulted in I07 individual projects concerned with the problem of labour market integration and social inclusion of migrants and ethnicized groups. The project descriptions are generally between three and ten pages long and describe the ways of working and the goals of the project as well as the specific problems the project sought to solve. Additional information in every project description included project owner, the grant support from the ESF, the total budget for the project, what period the project was active, and in what region. A coherent set of empirical material from the project description was constructed through a systematic reading of the I07 project descriptions.

Since the article was focusing on how the targeted subjects were constructed and problematized as lifelong learners, all the project descriptions were analyzed using the following analytical questions: Who are

8 This search of the project bank was carried out in February, 2011; hence the results may differ if a search was to be carried out today. The search words in Swedish: Utländsk, invandrare och flykting. 
the targeted subjects? How are the targeted subjects supposed to learn? Why are these subjects in need of learning? What are the targeted subjects supposed to learn?

In the first step of the analysis, the empirical material was categorized according to these questions. This was done by creating a document in which each project name was written as a heading. Under these 'project-name-headings' I wrote the analytical questions. Then I read all the project descriptions and copied relevant quotes and phrases and matched them to the analytical questions, as I saw fit. This process also involved creating new categories under certain project-name-headings when I found pieces of text that seemed relevant but were hard to match to any of the pre-posed questions. This process resulted in an empirical body of material comprising 175 pages of text.

In the second step of the analysis, re-occurring discourses concerning the formation and learning of the targeted groups were identified by closely reading the empirical material and using search words in the document for certain issues I was interested in analyzing. Out of the I07 project descriptions, a smaller number of projects (I4) were strategically selected for more thorough analysis as being typical of the re-occurring discourses identified. The project descriptions were analyzed as discourses that constructed unemployed migrants as learning subjects.

The motivation of the first article was to create a broader understanding of the governmentality of the projects. This kind of broad investigation can be useful to get to know the field and to create an overarching view of what the projects are about. Who runs them and owns them? How big or small are they? What groups are problematized and how? What kinds of techniques ought to be used to solve the problems described?

Since my interest lies in analyzing ethnicized un/employability I searched for sites where this phenomenon was likely to appear. A significant result from the first article, as well as from previous research (Thörnquist 20II), was that the ESF is co-financing projects which target two specific groups based on nationality and ethnicity - Somalis and Roma.

In contrast to the broader range of projects analyzed in the first article, the second article, Ethnicized un/employability, is a case study of one specific project named Somalis go into businesses. This article is designed 
as a case study, where one particular project targeting unemployed Somalis is analyzed as an illustrative case of how un/employability may be ethnicized. To choose unemployed Somalis as a specific case of ethnicized un/employability can be described as a purposive sampling which follows the rationality of the empirical material. The Swedish ESF's official website, in describing its own projects, identifies Somalis as one of the 'foreign-born ethnic groups' who are defined as the hardest to 'integrate within the Swedish labour market' (ESF 2013a). Also, prior research pinpoints Somalis as a specific group constructed as in need of specific measures (Thörnquist 20II). Thus I view the analysis of a project targeting Somalis as an instrumental case, which creates opportunities for in-depth analysis providing a detailed understanding of the rationalities of ethnicized un/employability (cf. Creswell 2013).

The method has similarities to 'netnography' (Kozinets 20I0) in which analyzed discourses are retrieved from the internet. In using this method I have tried to find out as much information as possible about the specific project from different online sources. During this work of searching empirical material I found several relevant empirical sources including the project's self-description in the ESF project bank, electronic newsletters, a handbook produced by the project leader (Rolfson n.d) concerning the work with Somalis, and the ESF's evaluation of the project (Wallin 20I2). The material was then analyzed with the overarching question of how ethnicity is constructed in relation to discourses of un/ employability. I read and re-read the empirical texts with the following questions as analytical 'glasses': How are the ethnicized Others, i.e. the unemployed Somalis, problematized, and in relation to what? What techniques are deployed to address the problems constructed? What are constructed as the normative qualities and characteristics of the employable subject?

The third article, Exploring misery discourses, analyzes projects which target Roma as a particularly problematized group. The reason for choosing Roma is similar to the reason in the article that analyzes a project targeting Somalis. However, for this article I did not concentrate on one specific project only, but sought to understand the multiplicity of projects targeting Roma.

The main empirical material analyzed in this article consisted of I 8 project descriptions found in the ESF project data bank by using the 
search word 'Roma'. The analyzed projects existed during the ESF programme period of $2007-2013$, and the timespan of the projects ranged from six months to three years. The analyzed projects targeting the Roma were driven by a range of organizations, from civil society organizations such as adult education providers (eight projects), to universities (two projects), county administrative boards and municipalities (seven projects), and the public employment office (one project).

From a governmentality perspective, the project descriptions are analyzed as discourses problematizing the Roma as learning subjects (cf. Fejes 20I4). In the analysis, the project descriptions are related to national (Skr. 20II/I 2:56; SOU 20I0:55) as well as European policy documents (European Commission 20II; ESF 2007) focusing on the inclusion of Roma in contemporary Europe.

Further, in order to deepen the analysis, I historicize the contemporary problematizations of the Roma through a parallel analysis of a government report from the I950s concerning the situation of the Roma (SOU I956: 43). The I950s was a period when the Swedish politics targeting Roma was shifting from a previous, more openly racist discourse to a more benign approach seeking to assimilate the Roma population in the majority society through schooling and regular housing (Selling 2013). This analytical strategy creates a contrast to the contemporary project descriptions, making visible the similarities and differences in the ways in which the Roma have been problematized in two distinct periods.

The fourth article, Rationalities of exclusionary inclusion, is based mainly on the ethnographic fieldwork carried out in 2009 and 2010 for TIA. It consists of interviews with unemployed people participating in labour market projects as well as interviews with staff working in these projects, and participant observations in several ESF projects. The fieldwork was carried out in order to observe the practices of ESF projects and to interview project participants and employees with an interest in detailed descriptions of everyday life and practices.

The ethnographic fieldwork carried out in TIA concentrated on six different ESF projects in Sweden. In the first project, I carried out nine days of participant observation and three interviews (two with participants and one with an employee). In the second, I interviewed two job coaches employed in the project. In the third and the fourth projects, I interviewed one job coach in each project. In the fifth, I carried out two 
days of participant observation and conducted interviews with two project employees. In the sixth, I carried out four days of participant observation and interviewed the project leader and an educator employed in the project, as well as the project employee responsible for work placements. In total, the ethnographic material consisted of I 5 days of participant observation. Field notes were taken directly on site and were elaborated on in relation to the observations and to the tweleve qualitative research interviews which spanned from one to two hours each. The interviews were recorded and transcribed in their entirety.

In addition to the ethnographic fieldwork carried out in TIA, analyzing and reading related policy documents, and participating in conferences, meetings and workshops arranged by the ESF, laid the foundation for my understanding of what the ESF projects were about - how their everyday practices were played out; what difficulties they experienced in running and planning ESF projects, and how they constructed the social problems they were engaged in and were working with.

For the purpose of article four in the thesis, I revisited the ethnographic material and chose empirical samples which illustrated the main argument of the article - that practices of social inclusion are embedded in discourses of exclusion. This approach nuances and creates a contrast with the empirical findings from the project descriptions and the policy documents as the analysis also focuses on opposition in power relationships - something which is hard to analyze in the project descriptions and policies analyzed in the first three articles. While such documents are useful for making the constructions and problematizations of targeted groups visible, they do not capture the everyday opposition to dominant discourses occurring in the projects (cf. Bröckling et al. 20I I). Such opposition is important to include in the analysis as it is an intrinsic part of any power relationship, thus shaping the way power is exercised (Foucault I997b). By engaging in an ethnographic approach, the dynamics of everyday power struggles taking place in the ESF projects can also be highlighted (cf. Brady 20I4).

\section{Ethical considerations and reflections}

Research ethics are not static, but changes continuously with the surrounding society. Discussions on research ethics took off after the Sec- 
ond World War when ethical codices for different areas of research were formulated. Different types of research also invoke different ethical considerations and reflections (Hermerén 20II). One societal change that has affected the ethical considerations of this thesis is the growth of the internet. A majority of the empirical material in this thesis was gathered online. Whether the web-based empirical material is public or private becomes a question of ethical concern. I have practised the principle that if the material can be reached by the public without any passwords or registration, I consider the material to be public. This means that I have not asked the persons responsible for or mentioned in the empirical material gathered online for permission to conduct research on these texts. However, I have followed the principle of confidentiality in so far as neither names nor personal information is published in this thesis. In the interviews and ethnographic fieldwork, the research ethical praxis of confidentiality and informed consent were deployed.

An important ethical question is whether I, as a researcher, contribute to further stigmatizing of certain disadvantaged groups just by focusing on them in my analysis. By accepting and following established categorizations such as immigrants, Somalis, and Roma, there is always a danger that one might reproduce dominant conceptions of ethnicity (cf. Gunaratnam 2003). A strategy to tackle this dilemma is put forward by Gunaratnam (2003) in terms of working both with and against ethnic categories. This strategy includes drawing attention to the constructed nature of concepts such as race and ethnicity. By doing so, one can avoid essentialist views and reifying the categories one is analyzing. So, due to the lack of more suitable concepts, I use ethnicized categorizations such as Somalis and Roma, since this is part of a vocabulary that is predominant in the empirical material analyzed in this thesis. But my focus is on how such ethnicization is produced and practised rather than on what the problems of Somalis and Roma on the labour market in Sweden really are. My analytical focus is on problematizations rather than what the problem actually is.

This issue is related to a wider problem: as a researcher of discourses and constructions of subjectivities, I am also inevitably part of constructing discourses and subjectivities. There is no way of separating oneself from the discourse one is analyzing (Fejes 2006). Speaking from an academic position, I have inescapably become part of the 'games of truth' 
regarding what is going on in the labour market projects targeting unemployed ethnicized groups. This calls for a reflective attitude towards how I portray the different subjects involved in the analysis, what discourses I construct regarding the problem of ethnicized un/employability, and what claims to knowledge I make. This problem is being tackled, as I consider that the knowledge produced in this thesis is situated and comes from a certain perspective. This means that the results might have been different if other methods where used, or if other analytical approaches were adopted, or if other questions were asked. However, this is a feature of most, if not all, social research. If handled in ethically responsible and scientifically sound ways, it does not affect the relevance of my conclusions. 


\section{SUMMARY OF THE ARTICLES}

Below I present a short introduction to and summary of the conclusions and results of each article. The disposition of the articles is the following: the first article focuses on how learning relates to Swedishness and employability in the ESF projects; the second and third provide an indepth analysis of Somalis and Roma as targeted groups, and the fourth analyzes the overarching rationality of exclusionary inclusion identified in the projects.

\section{Article I}

Vesterberg (2015) 'Learning to be Swedish: Governing Migrants in Labour Market Projects', Studies in Continuing Education. 37(3): 302-3 I 6.

This article focuses on adult learning in labour market projects which target unemployed migrants in Sweden. Drawing on a Foucauldian analysis of governmentality, the results of the study problematize the ways in which such projects produce individualizing discourses - targeting individuals and constructing them as responsible for their position as unemployed. The notion of social competency is analyzed here as a way of constructing the unemployed migrants as not yet employable. These results raise a number of issues of great concern for the inclusion of migrants in the labour market, as they highlight both a rationality of inclusive ambitions targeting unemployed migrants and the ethnicized discourses of Othering that imbue these learning practices.

Who are the targeted subjects in the projects? The target groups are generally not explicitly defined through ethnicity. Rather, the target groups are defined primarily by exclusion from the category of Swedishness. By using terms such as non-Nordic background, foreign-born, and immigrants the target groups are constructed as non-Swedes. However, two specifically problematized groups are explicitly constructed by ethnicity: Somalis and Roma.

How and what are the targeted subjects supposed to learn? The project descriptions construct unemployment among migrants as an individual problem and a responsibility that needs to be dealt with by unemployed migrants themselves (cf. Fejes 20I0; Garsten and Jacobsson 
2004). Here, the migrant is portrayed as a 'problematic learner' (Brine 2006). The projects direct a range of individualizing techniques - such as coaching, individual action plans, and empowerment - at the individual (Wright Nielsen 2009), rendering her able, willing, and motivated to learn certain skills that are deemed desirable to make her employable in the post-industrial knowledge economy. One of these highly valued skills is social competency, and building it entails enhancing not only the unemployed migrant's position on the labour market but also the migrant's entire social life. Learning social competency is constructed as an all-embracing activity fostering socially competent behaviour. In line with this process, interacting with 'Swedes' in 'natural environments', such as civil society (Rose I999a), is seen as particularly important in facilitating social inclusion and employability.

Another prominent feature of learning to become Swedish through employability, is gender equality. Governing through gender equality makes migrants governable by constructing boundaries between Swedishness and Otherness. In the projects, distinctions between Swedes and Others are made when constructing 'us' as progressive and equal, and 'them' as more or less patriarchal, traditional, and unequal (cf. Lundstedt 2005; Wright Nielsen 2009; Åse 20I I). It is seen as crucial that migrants, in order to become more gender-equal, interact with 'Swedes'. Such interaction is supposed to influence the targeted migrants, making them more gender-equal - in other words, more Swedish.

The rationality underpinning the interaction with 'Swedes', as encouraged in the projects, is the following: if migrants interact with 'Swedes' they will develop the social competency as well as the gender-equal mentalities necessary to make them employable on the Swedish labour market, and eventually they will learn to become Swedish. According to this rationality, Swedishness appears to be something that is potentially 'contagious'.

Why are the targeted subjects in need of intervention? The migrants are constructed as in need of interventions owing to their ascribed deficits in terms of motivation, self-esteem, social competency, and gender equality (Vesterberg 20I3; Åse 20II). The targeted migrants are in a way constructed in a predominantly Western discourse as representing the opposite of an employable subject. The rationality of the projects is to render the targeted migrants able, willing, and motivated to learn how 
to become employable according to the current norms and values of the host country - in this particular case, the norms and values of Swedishness. Here, there is an explicit targeting of two specific 'ethnic' groups, constructed as particularly problematic in relation to the labour market - Somalis and Roma.

\section{Article II}

Vesterberg (2013) 'Ethnicized Un/employability: Problematized Others and the Shaping of Advanced Liberal Subjects', Ephemera. Theory and Politics in Organization. I3(4): 737-757.

This article suggests some analytical tools for theoretically informed qualitative research of the nexus of employability and ethnicity. A governmentality perspective, inspired by Foucault and others who have elaborated on his thoughts, constitutes the analytical approach of the article. This approach directs the analytical focus towards problematizations and how the conduct of the governed subjects is guided.

In the article, I suggest that the concepts of problematized Others and advanced liberal subjects are useful in order to analyze how Otherness (based on notions of ethnic differences) is constructed as problematic in relation to contemporary Western norms of who constitutes an employable subject. This conceptual dichotomy is not to be understood as a set of neat and clear-cut categories, but rather as a starting point for thinking about the issue of ethnicized un/employability. To open up the analytical scope to a broad view of how un/employability can be ethnicized, it is important to recognize that subjects are positioned and constructed within a continuum that stretches from unemployable to the normative ideals of employability.

The concept of problematized Others, who are subjects often categorized as unemployable 'immigrants' or 'ethnic minorities', is inspired by Said (I979) and his influential work on Orientalism. The advanced liberal subjects, on the other hand, are subjects who meet contemporary normative standards of being employable. The concept of advanced liberal subjects is inspired by the work of Rose (r999a) and his discussion on contemporary Western societies as governed by advanced liberal rule. The prominent feature of advanced liberal subjects is that they have adopted an attitude and a sense of self that is in accord with the prevail- 
ing norms of advanced liberal societies. The two categories of advanced liberal subjects and problematized Others are used in this article to analyze the constructions of those perceived today as employable citizens, and those who are problematized as unemployable.

The analytical tools and the analytical approach are then employed using an empirical example. The analysis shows how the employability of a certain disadvantaged group - unemployed Somalis in Sweden - is problematized in the context of a labour market project co-funded by the ESF. The article discusses how different techniques, such as CV-writing, personal action plans, guidance, and job interview training, are deployed in order to reshape these problematized and ethnicized Others into advanced liberal subjects, or into employable individuals.

The construction of ethnicized Otherness becomes crucial in governing unemployed Somalis. Somalis are, in many respects, constructed as a group that is the direct opposite of the ideal citizen of advanced liberal societies. 'They' are constructed as patriarchal, in contrast to 'us' who are gender-equal; as illegal and idle due to the habit of chewing khat; and as too distracted and too unmotivated to engage in labour. Although 'their' culture is seen as a potential resource of entrepreneurialism, this aspect is seen as being hindered from flourishing by the prohibition of interest in the Koran. The main finding of the article is that unemployed Somalis in the project were constructed through discourses of Otherness, portraying them as 'different' in terms of ethnicity.

\section{Article III}

Vesterberg (2016a) 'Exploring Misery Discourses: Problematized Roma in Labour Market Projects', European Journal for Research on Education and Learning for Adults. 7(I): 25-40.

The aim of this article is to analyze learning practices in labour market projects co-financed by the ESF targeting unemployed Roma in Sweden. The main empirical material analyzed consists of I 8 self-descriptions from ESF projects. The self-descriptions are related to national as well as European policy documents dealing with the integration of the Roma in contemporary Europe and in Sweden in the I950s. The analytical perspective of the study is inspired by Foucault and other scholars who have elaborated on the concepts of governmentality and genealogy. Adopting 
a governmentality perspective, the analysis focuses on different problematizations and the discursive positioning of the Roma subjects.

The analysis shows that the European Commission, the Swedish government in the I950s as well as today, and labour market projects targeting Roma all have a longstanding concern about the welfare of Roma. However, various discourses position the Roma in more or less miserable situations. Four such discourses of miseries among the Roma have been identified: socioeconomic miseries, problematizing the general social and economic situation of unemployed Roma; educational miseries, problematizing the lack of education among Roma; gendered miseries, problematizing lack of gender equality among Roma, and embodied and medicalized miseries, problematizing the physical as well as psychological health of Roma.

All these discursive miseries shape the subject position of unemployed Roma as being in need of basic training in order to become educable as well as employable. Through the discursive miseries, the targeted Roma are constructed as a group that is socially excluded, not least through the omnipresent discourse of isolation, which is highlighted in the article. The main discrepancies between contemporary problematizations and those from the I950s are that the Roma miseries of the I950s were constructed with a more explicit focus on societal structures, such as housing and changes in the labour market. Today there is a greater emphasis on individualizing problematizations in terms of low self-esteem and psychological illnesses where the remedies predominantly are found in the will to strengthen the individual through various techniques of empowerment (Cruikshank I999).

Roma subjects are constituted through discourses of isolation, deprivation, substance abuse, gender inequalities, and poor education. Such positioning of the targeted subjects within discourses imbued by various miseries also produces knowledge about the Roma, constructing them as problematic, unemployable, and in need of special interventions, and thus making them governable in a variety of ways. Positioning Roma in socioeconomic, educational, embodied/medicalized, and gendered miseries puts them in the position of being completely opposite to what is normatively constructed as an 'employable individual' in contemporary Sweden. 
In relation to contemporary European efforts of building a 'learning society' inhabited by 'lifelong learners' (Masschelein et al., 2007), the Roma is problematized, not least in terms of lacking education (Miskovic, 20I3). Thus, Roma can be seen as non-traditional lifelong learners. Inviting Roma, as a marginalised and non-traditional group, to participate in adult education therefore becomes important. But, as the results of this article show, it is equally important to reflect upon if, how and why Roma are positioned in discourses of misery when engaged in facilitating learning for Roma or other marginalised and disadvantaged groups.

\section{Article IV}

Vesterberg (forthcoming 20I6b) 'Rationalities of Exclusionary Inclusion: Producing Others while Combatting Social Exclusion'. Accepted for publication in the edited volume (Neergaard, A., Schierup, C-U., and Ålund, A.) (eds.) Reimagineering the Nation. Frankfurt: Peter Lang.

The aim of this chapter is to problematize a consensus found among a number of different actors such as policymakers, providers of labour market projects, and street level practitioners working in projects which target unemployed ethnicized groups. The consensus, or 'the truth', that has been identified consists of a certainty that labour market projects targeting unemployed migrants increases employability among the targeted populations, and hence helps to combat social exclusion, and effectively generates inclusion. In achieving this aim, I pose the following analytical questions: How is exclusion produced when seeking to create social inclusion through enhanced employability? What rationalities and truths underlie the practices of exclusionary inclusion? What opposition to dominant discourses on employability can be found in the practices which seek to create social inclusion?

Drawing on ethnographic research, the analysis examines how project participants can exercise opposition to dominant discourses and destabilize the truths regarding inclusion and employability proclaimed by project employees. This chapter addresses this issue and aims to problematize that, although huge efforts have been made in order to facilitate social inclusion, ethnicized social exclusion still poses a most tangible social and political problem. 
The results of this chapter reveal a rationality that constructs exclusion of the targeted groups as essential for working with inclusion. In order to become included in societal normality one first needs to be positioned as excluded and deviant. The same rationality operates when the goal is to enhance employability: in order to make someone employable, one has to first position the targeted subject as unemployable.

This has the effect that in practices of inclusion, such as the ESF projects which target unemployed migrants, there is an emphasis on constructing the targeted subjects as 'different' and to ethnicize the target groups. Even though practices of inclusion are trying to produce 'sameness', to transform 'ethnicized Others' into 'advanced liberal subjects', the boundary with those who are understood as 'different' must be constantly maintained (Tesfahuney and Grip 2007).

In other words, the rationality underpinning and shaping subjectivities is that the targeted subjects need to be constructed as problematic in relation to what one is trying to achieve - inclusion needs exclusion; employability needs unemployability, and sameness needs Otherness. Otherwise, measures striving to produce certain subjects would appear irrational, or at least rather pointless. In this way, ethnicized Otherness is being produced when combatting the social exclusion of unemployed migrants; a rationality I have chosen to call exclusionary inclusion. The terminology of exclusionary inclusion has similarities to Agamben's (1998) discussion about Homo Sacer as a specific subject trapped in a paradoxical state of inclusionary exclusion and exclusionary inclusion. Agamben argues that a fundamental conceptual divide in Western politics is that of exclusion and inclusion, not least exemplified by the figure of 'the refugee'. Elaborating on Agamben's thoughts, Diken (2004) argues that the exclusion of migrants and refugees always are followed by inclusive measures. This rationality is part of the relationship between 'us' and 'them', indicating how rationalities of exclusionary inclusion operate when unemployed migrants are constructed as excluded in order to become includable.

As shown in the analysis, there is also opposition to the dominant discourses produced in the projects, concerning how employability is supposed to lead to inclusion. Project participants can oppose the 'truths' delivered by experts. Struggles over meaning concerning the techniques of inclusion through employability are played out in 'games of truth', 
and in this way dominant discourses are destabilized. The analysis shows that the construction of subjects as employable is not a simple, neat, top-down process. Rather it takes place in power relationships that consist of both the experts' attempts to 'conduct the conduct' of the targeted subjects, and the counter-conducts staged by project participants in language games concerned with contesting truths regarding the labour market projects. 


\section{CONCLUDING DISCUSSION}

In summarizing the key contributions and results of this thesis, I will start by arguing for the possible implications in terms of policymaking and the development of practices targeting marginalized groups that this thesis may contribute to. Thereafter, I will discuss what I consider as the methodological, theoretical, and analytical findings of the thesis. Finally, I will summarize the results by recapitulating the research questions posed in the introduction, and by focusing on the what, who, why, and how of governing.

Sweden has, for a long time, been well known for its generous and progressive immigration policies (Schierup, Hansen, and Castles 2006), as well as its universal welfare policies (Esping-Andersen 1990). Sweden's official institutions embrace values such as equal rights for all and reject racism (Pred 2000; Schierup and Ålund 20I I). For instance, the ESF uses slogans such as 'jobs and new opportunities for all' and 'giving a chance to all' which indicate a political ambition to create a more inclusive society.

In relation to these political ambitions, the results of this thesis have implications for professionals in the field of migrant and ethnic inclusion. Encouraging marginalized groups to become employable and included in society is important for both policymakers and practitioners. But, as the results of this thesis show, it is equally important to reflect upon whether, how, and why the targeted groups are positioned in discourses of misery, and constructed as deviant Others in relation to norms of 'Swedishness', when seeking to facilitate learning and employability for unemployed marginalized and disadvantaged groups.

As Agamben (1998) argues, discourses of inclusion and exclusion are prominent in Western politics, which is apparent not least in practices targeting migrants. Diken (2004) argues that the exclusion of migrants is an inherent part of the relationship between 'us' and 'them' whereas 'we' invite the excluded Others to become included. This raises questions concerning who is constructed as belonging to the nation and who is not and on what terms the Others may become included. The 'imagined community' of the nation (Anderson 2006) and 'the national order of things' (Malkki I997) inevitably produces divisions between 'us' and 
'them', which is apparent not least in our present time, which have been called 'the age of migration' (Castles and Miller 2009; Dahlstedt and Neergaard 2015).

The thesis also shows that no 'truth' is absolute, and that there is always room for opposition and contestation in the language games of the everyday practices of social inclusion. Truths are contingent, thus practices of inclusion are never totally closed to new interventions. New ways of thinking about inclusion and subjectivities are always possible (cf. Cruikshank I999) - for the targeted subjects themselves as well as for the experts engaged in practices of inclusion.

Methodologically, this thesis contributes to an ongoing effort of connecting discourse-oriented governmentality studies with ethnographic methods such as qualitative interviews and participant observation (cf. Brady 2014; Fogde 2009). Analyzing governing in practice as 'games of truth', captured through ethnographic methods, has proven fruitful as a way of analyzing opposition in power relationships.

Theoretically and empirically, this thesis contributes to the study of employability by analyzing how employability is being ethnicized in certain ways. By introducing some analytically useful concepts for qualitative analysis of ethnicized employability, my hope is that the thesis also contributes to further theorization and analysis of the ways in which marginalized groups are governed. The concepts of problematized Others and advanced liberal subjects can be fruitful as a starting point for analyzing the continuum between those constructed as deviant and those constructed as normal in contemporary Western societies. The rationality of exclusionary inclusion, identified as operating in measures of inclusion through employability, can also prove useful for further analyzing similar practices.

What is problematized within practices that target unemployed ethnicized groups? As this thesis shows, the task of making migrants and ethnicized target groups employable in labour market projects in Sweden is imbued by discourses of Swedishness and Otherness, as well as various rationalities of exclusion. The normative standards of what it means to be employable relates to discourses of Swedishness. Thus, the unemployed project participants constructed as non-Swedish are expected to learn to become more Swedish. 
Who is to be governed and who is governing? Unemployed Somalis and Roma are the two target groups identified as explicitly constructed on the basis of nationality or ethnicity. Both groups are constructed as standing in stark contrast to contemporary Western ideals of employability. Somalis and Roma are in various ways constructed as problematic and deviant in relation to the norms of an employable citizen. Apart from Somalis and Roma, the ESF's target groups are generally constructed through their lack of Swedishness, formulated for instance as 'foreign background', 'non-Nordic ethnicity', or 'immigrant'. I have called those in the position of exercising the governing 'experts of employability', relating to Rose's (r999b) thoughts on the role of expertise in the governing of advanced liberal societies.

Why are unemployed ethnicized groups constructed as problematic in relation to the labour market, and understood as in need of specific interventions? The unemployed Somalis are ethnicized as Others and problematized as patriarchal, khat-chewing, and idle - in contrast to the gender-equal and motivated 'Swedes'. Unemployed Roma are positioned within various misery discourses constructing them as lacking important qualities such as education, good health, and gender equality. Altogether these problematizations of ethnicized target groups renders them governable and constructs them as targets for measures of inclusion through employability, such as the ESF projects.

A prominent rationality identified in the practices of inclusion is that the targeted subjects, in order to become includable, first must be constructed as excluded. In this rationality, being included is closely related to being aligned with societal norms, and being positioned as excluded means being constructed as deviant in various ways. Thus, the practices of inclusion seek to normalize the problematized and excluded subjects into being included in society and becoming employable. This rationality has been analyzed in terms of an exclusionary inclusion which has emerged as central in the studied projects. This rationality may provide an understanding as to why the target groups are constructed as problematic: measures of inclusion need excluded groups to target. In order to be able to include someone, that person must first be made includable. This rationality relates to the discourse of the nation state which borders produces certain subjects as naturally belonging, as unproblematically included, whilst problematizing Others as foreigners and strangers - as 
excluded, but potentially includable. The same rationality is also at play when enhancing employability - in order to make someone employable, one first has to position the person as unemployable, otherwise measures seeking to achieve social inclusion through enhanced employability would appear irrational, or at least pointless. In other words, normality presupposes deviance.

How are the targeted groups to be governed? As shown in this thesis, a range of individualizing techniques such as individual action plans, individual guidance, and job coaching are deployed in the projects. Such techniques individualize the problem of unemployment as they seek to strengthen and empower each participant. At the same time, the individualizing techniques construct the project participants as responsible for their unemployment - thus responsibilizing the target groups.

In using ethnographic methods, this thesis also shows that the unemployed project participants oppose the dominant discourses and do not necessarily agree with the norms and standards of how to become an included and employable citizen. This opposition illustrates that power is never a one-way relationship, but is always accompanied by resistance (Foucault 2002). It further illustrates that governing can be - and is - interrupted and destabilized through 'games of truth' played out between the project participants and the employees.

To say what would be a 'good' or 'right' practice or policy of inclusion is the topic for a different investigation than this one. It is my hope that the present studies can serve as a starting point to reflect on how policies of inclusion are at risk of excluding and categorizing people in different ways, which can sometimes be highly problematic in relation to the explicit ambitions of these policies. Overall, this thesis highlights different aspects of practices of inclusion targeting migrants and ethnicized groups that can be seen as both problematic and sometimes contradictory. Among these aspects we find tendencies to individualize unemployment, thus making the unemployed project participants responsible for their situation. But we also find the using of ethnicity in ways that are likely to exaggerate the targeted groups' Otherness in relation to a normalized Swedishness, and thus widen the gap between 'us' and 'them', when the explicit goal is often the opposite - to create a more inclusive society and to combat social exclusion. 


\section{SAMMANFATTNING}

I avhandlingen studeras arbetsmarknadspolitiska åtgärder, i form av projekt finansierade av Europeiska socialfonden (ESF), riktade mot arbetslösa migranter och etnifierade grupper. Analysen är kvalitativ, diskursorienterad och utgår från Foucaults begrepp governmentality. Mer specifikt belyses hur projektens målgrupper etnifieras genom diskurser om anställningsbarhet och lärande. Avhandlingen består av fyra artiklar. I de tre första artiklarna fokuseras främst hur projekten framställer sig själva genom projektbeskrivningar i ESFs projektbank. Den fjärde artikeln utgår främst från etnografiskt material från deltagande observationer och kvalitativa intervjuer.

Avhandlingens första artikel ger en övergripande bild av de studerade projekten. Här analyseras hur normer om anställningsbarhet bygger på att projektdeltagarna förväntas lära sig 'svenskhet' och på så vis konstrueras som icke-svenska. I projekten används individualiserande tekniker såsom individuella handlingsplaner, individuell jobbcoachning och vägledning, vilket konstruerar projektdeltagarna som ansvariga för sin situation som arbetslösa. Social kompetens och jämställdhet är två diskurser som i projekten används för att positionera projektdeltagarna som oanställningsbara och i behov av att lära sig 'svenskhet'. I studien framkommer även att ESF finansierar projekt riktade till två målgrupper på grund av deras nationalitet och/eller etnicitet: somalier och romer.

Den andra artikeln är en studie av ett specifikt projekt riktat till arbetslösa somalier i Sverige. Artikelns resultat pekar på hur somalier i projektet på olika sätt konstrueras som problematiska och avvikande i relation till normer om hur en anställningsbar individ förväntas vara. I studien introduceras två begrepp som kan vara användbara som en utgångspunkt för analyser av hur anställningsbarhet etnifieras, men även mer generellt hur etnifierad normalitet och avvikelse konstrueras i samtida västerländska samhällen. Begreppen problematiserade Andra och avancerade liberala subjekt indikerar två olika subjektspositioner inom ett spektrum av vad som konstrueras som avvikande (oanställningsbar) respektive normalt (anställningsbar). Begreppet problematiserade Andra är inspirerat av Said (I979) och hans arbete kring Orientalism och hur Orienten i en västerländsk diskurs har konstruerats som bakåtsträvande 
och traditionell i motsats till det progressiva och moderna Väst. Begreppet avancerade liberala subjekt refererar till de subjekt som lever upp till samtida normer om att vara anställningsbar. Begreppet är inspirerat av Rose (I999a) och hans tankar om avancerad liberal styrning. Det avancerade liberala subjektet lever därmed upp till normer om att vara entreprenöriell, flexibel och att betrakta sig själv i första hand som en ekonomisk varelse.

Studien visar hur arbetslösa somalier i ett arbetsmarknadsprojekt etnifieras och på många sätt konstrueras som en motsats till ideal om det avancerade liberala subjektet. Projektdeltagarna konstrueras som problematiska Andra bland annat genom att förstås som icke jämställda, khat-tuggande, lata och omotiverade att arbeta.

I den tredje artikeln analyseras hur projekt riktade mot arbetslösa romer konstruerar målgruppen genom olika eländes- och bristdiskurser. En utgångspunkt är att romer under lång tid har varit en målgrupp för olika sorters insatser, både i Sverige och i Europa. Inte sällan har dessa insatser varit av destruktiv karaktär såsom förföljelse, diskriminering och i värsta fall försök till förintelse. Myndigheters insatser har på senare tid präglats mer av välvilja och en vilja att assimilera eller integrera romer i 'majoritetssamhället'. I artikeln analyseras samtida empiriskt material i form av I 8 ESF-projekt som riktar sig specifikt mot romer. Som en kontrast till dessa projekt analyseras även en statlig offentlig utredning (SOU I956: 43) från I950-talet.

Analysen pekar på såväl likheter som olikheter i hur romer problematiseras idag och på I950-talet. I kontrast till dagens mer individfokuserade problematiseringar fanns det på 1950-talet en större benägenhet att också se till strukturella problem som hindrade romer att assimileras (vilket var idealet) såsom en bristfällig bostadsmarknad och en förändrad arbetsmarknad. Fyra olika brist- och eländesdiskurser identifieras och analyseras som framträdande: socioekonomiska brister, bristande utbildning, bristande jämställdhet och bristande hälsa. Resultatet visar på hur dessa diskurser idag konstruerar arbetslösa romer som problematiska i relation till normer om att vara ett anställningsbart och lärande subjekt.

I den fjärde artikeln analyseras projekten såsom formade av en rationalitet som kan kallas exkluderande inkludering. Denna rationalitet har i avhandlingen framträtt som central i de studerade ESF-projekten och 
den består närmare bestämt i att målgrupperna för att kunna bli inkluderbara och anställningsbara tenderar att konstrueras som exkluderade och icke-anställningsbara. Denna rationalitet kan förstås enligt följande resonemang: för att det överhuvudtaget ska vara meningsfullt att ägna sig åt inkluderingssåtgärder genom stärkt anställningsbarhet behövs målgrupper som är exkluderade och ännu inte anställningsbara. Analysen indikerar att ett problem med denna rationalitet är att målgrupper etnifieras och konstrueras som avvikande och på så sätt riskerar att vidga gapet mellan 'dem' och 'oss' när målsättningen är att skapa integration och inkludering.

Genom en etnografisk ansats visar även artikeln hur dominerande diskurser om anställningsbarhet och inkludering möter motstånd från de arbetslösa projektdeltagarna, som inte alls okritiskt fogar sig efter de förväntningar som finns på dem. Vidare visar analysen att även de anställda i projekten, vars uppgift det är att implementera policy från ESF och EU, kan förhålla sig kritiska till de dominanta diskurser de har att jobba inom och på så sätt göra motstånd mot de 'sanningar' som har cementerats inom projekten.

Att säga vad som vore en 'bra' eller 'rätt' inkluderingspraktik ligger utanför denna avhandlings syfte. Däremot är det min förhoppning att studierna ska kunna fungera som utgångspunkt för att reflektera kring hur inkluderingsinsatser och arbetsmarknadsprojekt riskerar att sortera och kategorisera människor på olika sätt, som ibland kan vara problematiska i relation till vad insatserna vill uppnå. Sammantaget belyser denna avhandling olika aspekter av inkluderingsarbete riktat mot migranter och etnifierade målgrupper som kan ses som problematiska och ibland motsägelsefulla. Det handlar om tendenser att individualisera arbetslösheten och därmed i hög grad ansvariggöra projektdeltagare för sin situation. Det handlar också om att använda kultur och etnicitet på ett sätt som riskerar att förstärka målgruppernas 'annorlundahet' i relation till den 'svenskhet' som inte sällan blir synonymt med vad som uppfattas som normalt och på så sätt vidga gapet mellan 'vi' och 'dem' när den uttalade målsättningen ofta är det motsatta. 


\section{REFERENCES}

Agamben, G. (I998) Homo Sacer: Sovereign Power and Bare Life. Stanford: Stanford University Press.

Alvesson, M. (2003) Postmodernism och sambällsforskning. Malmö: Liber.

Anderson, B. (2006) Imagined Communities: Reflections on the Origin and Spread of Nationalism. Revised Edition. London: Verso.

Anderson, B. (2013) Us \& Them? The Dangerous Politics of Immigration Control. Oxford: Oxford University Press.

Andersson, P. and Guo, S. (2009) 'Governing through Non/recognition: The Missing " $\mathrm{R}$ ” in the PLAR for Immigrant Professionals in Canada and Sweden', International Journal of Lifelong Education. 28(4): 423-437.

Åse, C. (20I I) Moderna svenska individer: Lösningar och problembilder i beskrivningar av ESF-projekt. Linköping: Linköping University.

Behtoui, A. (2006) Unequal Opportunities: The Impact of Social Capital and Recruitment Methods on Immigrants and Their Children in the Swedish Labour Market. Linköping: Linköping studies in arts and science.

Berglund, T. and Schedin, S. (2009) 'Människan, arbetet och samhället', Berglund, T. and Schedin, S. (eds.) Arbetslivet. Lund: Studentlitteratur.

Beronius, M. (I994) Bidrag till de sociala undersökningarnas historia: Eller till den vetenskapliggiorda moralens genealogi. Stockholm: Brutus Östlings Bokförlag Symposion.

Bevir, M. (20I0) 'Rethinking Governmentality: Towards Genealogies of Governance', European Journal of Social Theory. I3 (4): 423-44I.

Bonfanti, S. (20I4) '“New Rules for Labour Immigration”: Delving into the 2008 Swedish Reform on Labour Migration and its Effects on Migrants' Well-being', International Migration and Integration. I $5(3): 37 \mathrm{I}-386$.

Boréus, K. (I994) Högervåg: Nyliberalismen och kampen om språket $i$ svensk debatt I969-1989. Stockholm: Stockholm University. 
Börjesson, M. and Palmblad, E. (2007) 'Introduktion', Börjesson, M. and Palmblad, E. (eds.) Diskursanalys i praktiken. Malmö: Liber. Brady, M. (20I4) 'Ethnographies of Neoliberal Governmentalities: From the Neoliberal Apparatus to Neoliberalism and Governmental Assemblages', Foucault Studies. I 8: I I-33.

Brine, J. (2006) 'Lifelong Learning and the Knowledge Economy: Those That Know and Those That Do Not-The Discourse of the European Union.' British Educational Research Journal. 32(5): 649-665. Bröckling, U., Krasmann, S. and Lemke, T. (eds.) (20I I) Governmentality: Current Issues and Future Challenges. London: Routledge.

Brubaker, R. (2006) Ethnicity Without Groups. Cambridge: Harvard University Press.

Carlbaum, S. (20II) 'Reforming Education: Gendered Constructions of Future Workers', Sjölander Egan, A. and Payne Gunnarsson, J. (eds.) Tracking Discourse: Politics, Identity and Social Change. Lund: Nordic Academic Press.

Carlbaum, S. (2012) Blir du anställningsbar lillela vän? Diskursiva konstruktioner av framtida medborgare i gymnasiereformer I 97 I $20 I$ I. Umeå: Statsvetenskapliga institutionen, Umeå University.

Carlson, B., Magnusson, K. and Rönnqvist, S. (2012) Somalier på arbetsmarknaden: Har Sverige något att lära. Stockholm: Fritzes.

Carmichael, F. and Woods, R. (2000) 'Ethnic Penalties in Unemployment and Occupational Attainment: Evidence for Britain', International Review of Applied Economics. I4(I): 7 I-98.

Carrera, S., Blockmans, S., Gros, D. and Guild, E. (2015) 'The EU's Response to the Refugee Crisis: Taking Stock and Setting Policy Priorities', Centre for European Policy Studies. 20(I 6): I-22.

Castles, S. and Miller, M. J. (2009) The Age of Migration: International Population Movements in the Modern World. Fourth edition. Basingstoke: Palgrave Macmillan.

Castles, S., Booth, H. and Wallace, T. (I984) Here for Good: Western Europe's New Ethnic Minorities. London: Pluto.

Chertkovskaya, E., Watt, P., Tramer, S. and Spoelstra, S. (20I3) 'Giving Notice to Employability', Ephemera. Theory \& Politics in Organization. I3 $(4)$ : 70I-7I 6.

Cohen, P. (I999) 'Introduction', Cohen, P. (ed.) New Ethnicities. Old Racisms. London: Zed. 
Conley, G.T. and Topa, G. (2002) 'Socio-economic Distance and Spatial Patterns in Unemployment', Journal of Applied Econometrics. I7 (4): 303-327.

Creswell, W.C. (2013) Qualitative Inquiry and Research Design: Choosing among Five Approaches. Third edition. London: Sage.

Cruikshank, B. (1999) The Will to Empower: Democratic Citizens and other Subjects. Ithaca: Cornell University Press.

Dahlstedt, M. and Neergaard, A. (eds.) (2015) International Migration and Ethnic Relations: Critical Perspectives. London: Routledge.

Dahlstedt, M. (2009a) 'Employability, Social Exclusion and Labour Market Policies in Sweden', Neergaard, A. (ed.) European Perspectives on Exclusion and Subordination: The Political Economy of Migration. Maastricht: Shaker.

Dahlstedt, M. (2009b) Aktiveringens politik: Demokrati och medborgarskap för ett nytt millennium. Malmö: Liber.

Davidsson, T. (2015) Understödets rationalitet: En genealogisk studie av arbetslinjen under kapitalismen. Malmö: Égalité.

Dean, M. (1995) 'Governing the Unemployed Self in an Active Society', Economy and Society. 24(4): 559-583.

Dean, M. (1996) 'Foucault, Government and the Unfolding of Authority', Barry, A., Osborne, T. and Rose, N. (eds.) Foucault and Political Reason: Liberalism, Neoliberalism and Rationalities of Government. Chicago: University of Chicago Press.

Dean, M. (1998) 'Administering Asceticism: Reworking the Ethical Life of the Unemployed Citizen', Dean, M. and Hindess, B. (eds.) Governing Australia. Cambridge: Cambridge University Press.

Dean, M. (2007) Governing Societies: Political Perspectives on Domestic and International Rule. Berkshire: Open University Press.

Dean, M. (2010) Governmentality: Power and Rule in Modern Society. Second edition. London: Sage.

Delgado, R. and Stefancic, J. (20I0) Critical Race Theory: An Introduction. Second edition. New York: New York University Press.

Diedrich, A. and Styhre, A. (2013) 'Constructing the Employable Immigrant: The Uses of Validation Practices in Sweden', Ephemera. Theory \& Politics in Organization. I3(4): 759-783.

Diken, B. (2004) 'From Refugee Camps to Gated Communities: Biopolitics and the End of the City', Citizenship Studies. 8(I): 83-106. 
Engstrand, A-K., Andersson, J. and Vesterberg, V. (2010) Bortom Lissabonstrategin: Om projektarbetares erfarenheter av inkluderingsarbete. Linköping: Linköping University.

ESF (2007) National Structural Fund Programme for Regional Competitiveness and Employment (ESF) 2007-2013. CCI number 2007SE052 POOOI.

Esping-Andersen, G. (1990) The Three Worlds of Welfare Capitalism. Cambridge: Polity.

Ettlinger, N. (20I I) 'Governmentality as Epistemology', Annals of the Association of American Geographers. IOI(3): 537-560.

European Commission. (20II) COM 20II:I73: An EU Framework for National Roma Integration. Strategies up to 2020. Brussels: European Commission

Fejes, A. (2006) Constructing the Adult Learner: A Governmentality Analysis. Linköping: Linköping University.

Fejes, A. (2010) 'Discourse on Employability: Constituting the Responsible Citizen', Studies in Continuing Education. 32(2): 89-IO2.

Fejes, A. (20I4). 'Lifelong Learning and Employability', Zarifis, G. and Gravani, M. (eds.) Challenging the 'European Area of Lifelong Learning'. Dordrecht: Springer.

Fejes, A. and Nicoll, K. (eds.) (2008) Foucault and Lifelong Learning: Governing the Subject. London: Routledge.

Fogde, M. (2008) 'Self-Governance in the Job Search: Regulative Guidelines in Job Seeking', Fejes, A. and Nicoll, K. (eds.) Foucault and Lifelong Learning: Governing the Subject. London: Routledge.

Fogde, M. (2009) The Work of Job Seeking: Studies on Career Advice for White-Collar Workers. Örebro: Örebro University.

Foucault, M. (1980) 'Truth and Power', Gordon, C. (ed.) Power/Knowledge: Selected Interviews and Other Writings 1972 - 1977. New York: Pantheon Books.

Foucault, M. (1981) 'The Order of Discourse', Young, R. (ed.) Untying the Text. London Routledge.

Foucault, M. (1983) 'The Subject and Power', Dreyfus, H. and Rabinow, P. (eds.) Michel Foucault: Beyond Structuralism and Hermeneutics. Second edition. Chicago: University of Chicago Press. 
Foucault, M. (I99I) 'Governmentality', Burchell G., Gordon, C. and Miller, P. (eds.) The Foucault Effect: Studies in Governmentality. Chicago: The University Of Chicago Press.

Foucault, M. (I997a) 'The Ethics of the Concern for Self as a Practice of Freedom', Rabinow, P. (ed.) Ethics, Subjectivity and Truth. New York: The New Press.

Foucault, M. (I997b) 'Sex, Power and the Politics of Identity', Rabinow,

P. (ed.) Ethics, Subjectivity and Truth. New York: The New Press.

Foucault, M. (2000) 'The Subject and Power', Faubion, J.D. (ed.) Power.

New York: The New Press.

Foucault, M. (2002) The History of Sexuality. Vol.I. The Will to Knowledge. Harmondsworth: Penguin.

Foucault, M. (2007a) The Birth of Biopolitics: Lectures at the Collége de France 1978 - 1979. New York: Palgrave Macmillan.

Foucault, M. (2007b) Security, Territory, Population: Lectures at the Collége de France I977 - I978. New York: Palgrave Macmillan.

Foucault, M. (2014) Wrong-Doing, Truth-Telling: The Function of Avowal in Justice. Brion, F and Harcourt, B.E. (eds.) Chicago: University of Chicago Press.

FRA (20I6) Romernas situation $i$ I I EU-medlemsstater: Kort sammanfattning av undersökningsresultaten. European Union Agency for Fundamental Rights. Available at: http://fra.europa.eu/sites/default/ files/fra_uploads/2 I09-FRA-Factsheet_ROMA_SV.pdf [Accessed 29 February 2016].

Garsten, C. and Jacobsson, K. (eds.) (2004) Learning to be Employable: New Agendas on Work, Responsibility and Learning in a Globalizing World. Basingstoke: Palgrave Macmillan.

Goldberg, D.T. (1993) Racist Culture: Philosophy and the Politics of Meaning. Oxford: Blackwell Publishing.

Goldberg, D.T. (2009) The Threat of Race: Reflections on Racial Neoliberalism. Oxford: Blackwell Publishing.

Gordon, C. (I99I) 'Governmental Rationality: An Introduction', Burchell, G., Gordon, C. and Miller, P. (eds.) The Foucault Effect: Studies in Governmentality. Chicago: The University of Chicago Press.

Gunaratnam, Y. (2003) Researching 'Race' and Ethnicity: Methods, Knowledge and Power. London: Sage. 
Guo, Y. (20I3) 'Language Policies and Programs for Adult Immigrants in Canada: A Critical Analysis', Canadian Ethnic Studies. 45(I-2): 23-4I.

Hale, J. (2007) European Social Fund: 50 Years of Investing in People. Luxembourg: Office for Official publications of the European Communities.

Hall, S. (1992) 'The West and the Rest: Discourse and Power', Hall, S. and Gieben, B. (eds.) Formations of Modernity: Understanding Modern Societies. Cambridge: Polity Press.

Hall, S. (1996) 'New Ethnicities', Morley, D. Chen, K.H. (eds.) Stuart Hall: Critical Dialogues in Cultural Studies. New York: Routledge. Hall, S. (2000) 'Old and New Identities: Old and New Ethnicities', Hesse, B. (ed.) Theories of Race and Racism: A Reader. London: Routledge.

Hamann, T.H. (2009) 'Neoliberalism, Governmentality, and Ethics', Foucault Studies. 6: 37 - 59 .

Hansen, P. and Hager, B. (2010) The Politics of European Citizenship: Deepening Contradictions in Social Rights and Migration Politics. New York: Berghahn Books.

Hermerén, G. (20I I) God forskningssed. Stockholm: Vetenskapsrådet. Hindess, B. (2005) 'Citizenship and Empire', Hansen, T.B. and Stepputat, F. (eds.) Sovereign Bodies, Citizens, Migrants and States in the Postcolonial World. Princeton: Princeton University Press.

Hörnqvist, M. (20I2) En annan Foucault: Maktens problematik. Stockholm: Carlsson Bokförlag.

Howarth, D. (2000) Discourse. Buckingham: Open University Press. Hübinette, T, Hörnfeldt, H, Farahani, F, and Rosales, R.L. (eds.) (20 I 2) $\mathrm{O} m$ ras och vithet $i$ det samtida Sverige. Botkyrka: Mångkulturellt Centrum.

Hultqvist, K and Petersson, K. (eds.) (1995) Foucault: Namnet på en modern vetenskaplig och filosofisk problematik. Stockholm: HLS förlag.

Inda, J.X. (2006) Targeting Immigrants: Government, Technology and Ethics. Oxford: Blackwell Publishing.

Jacobsson, K. (2004) 'A European Politics for Employability: The Political Discourse on Employability of the EU and the OECD', Garsten, $\mathrm{C}$ and Jacobsson, K. (eds.) (2004) Learning to be Employable: New 
Agendas on Work, Responsibility and Learning in a Globalizing World. Basingstoke: Palgrave Macmillan.

Junestav, M. (2004) Arbetslinjer i svensk socialpolitisk debatt och lagstiftning I930-200I. Uppsala: Uppsala University.

Klinthäll, M. and Urban, S. (2OI4) 'Second-Generation Immigrants in the Small-Business Sector in Sweden', Journal of Immigrant \& Refugee Studies. I 2(3): 210-232.

Kozinets, R.V. (2010) Netnography: Doing Ethnographic Research Online. Los Angeles: Sage.

Larsson, B., Letell, M. and Thörn, H. (eds.) (20I 2) Transformations of the Swedish Welfare State: From Social Engineering to Governance? Basingstoke: Palgrave Macmillan.

Larsson, J.K. (2015) Integrationen och arbetets marknad. Stockholm: Atlas.

Leslie, D. and Drinkwater, S. (1998) 'Staying on in Full-time Education: Reasons for Higher Participation Rates among Ethnic Minority Males and Females', Economica. 66(26I): 63-77.

Lundstedt, A. (2005) Vit governmentalitet: "Invandrarkvinnor" och textilhantverk - en diskursanalys. Stockholm: Arbetslivsinstitutet.

Malkki, L.H. (1997) Purity and Exile: Violence, Memory, National Cosmology among Hutu Refugees in Tanzania. Chicago: University Of Chicago Press.

Masschelein, J., Simons, M., Bröckling, U. and Pongratz, L. (eds.) (2007) The Learning Society from the Perspective of Governmentality. Oxford: Blackwell Publishing.

McKee, K. (2009) 'Post-Foucauldian Governmentality: What does it Offer Critical Social Policy Analysis?', Critical Social Policy. 29(3): 465-486.

McQuaid, R. W. and Lindsay, C. (2005) 'The Concept of Employability', Urban Studies. 42(2): 197-219.

Miles, R. and Brown, M. (2003) Racism. Second edition. New York: Routledge.

Miller, P. and Rose, N. (2008) Governing the present: Administering Economic, Social and Personal Life. Cambridge: Polity Press.

Mills, S. (1997) Discourse. New York: Routledge.

Ministry of Employment (20I I) Fickfakta 20 Io. Statistik om integration. Stockholm: Ministry of Employment. 
Ministry of Employment (2015) Statens budget 2015 i siffror. Government Offices of Sweden. Available at: http://www.regeringen.se/artiklar/20I 5/04/statens-budget-20I 5-i-siffror [Accessed 29 February 20I6].

Miskovic, M. (ed.) (2013). Roma Education in Europe: Practices, Policies and Politics. London: Routledge.

Neergaard, A., Schierup, C-U. and Ålund, A. (eds.) (forthcoming 2016) Reimagineering the Nation. Frankfurt: Peter Lang.

O'Farrell, C. (2005) Michel Foucault. London: Sage.

OECD (2015) Indicators of Immigrant Integration 20 I 5: Settling in. OECD Publishing: Paris.

Osman, A. (2006) 'Integrerande "praktiker" som arena för normalisering och disciplinering av utlandsfödda', Gunnarsson, E., Neergaard, A. and Nilsson, A. (eds.) Kors \& tvärs: Intersektionalitet och makt $i$ storstadens arbetsliv. Stockholm: Normal förlag.

Patton, P. (1979) 'Of Power and Prisons', Morris, M. and Patton, P. (eds.) Michel Foucault: Power/Truth/Strategy. Sydney: Feral publications.

Peralta, J. (2006) Den sjuka arbetslösheten: Svensk arbetsmarknadspolitik och dess praxis I978-2004. Uppsala: Uppsala University.

Petersson, J. (2009) 'Den aktiva arbetsmarknadspolitiken växer fram', Johansson, H. and Möller Horemann, I. (eds.) Aktivering: Arbetsmarknadspolitik och socialt arbete i förändring. Malmö: Liber.

Popkewitz, T.S. and Lindblad, S. (2000) 'Educational Governance and Social Inclusion and Exclusion', Discourse: Studies in Cultural Politics of Education. $2 \mathrm{I}(\mathrm{I}): 5-44$.

Popkewitz, T.S., Olsson, U. and Petersson, K. (2007) 'The Learning Society, the Unfinished Cosmopolitan, and Governing Education, Public Health and Crime Prevention at the Beginning of the Twenty-First Century', Masschelein, J., Simons, M., Bröckling, U. and Pongratz, L. (eds.) The Learning Society from the Perspective of Governmentality. Oxford: Blackwell Publishing.

Porte, de la, C. and Jacobsson, K. (2012) 'Social Investment or Recommodification?', Morel, N., Palier, B. and Palme, J. (eds.) Towards a Social Investment Welfare State?. Bristol: Policy Press. 
Pred, A. (2000) Even in Sweden: Racisms, Racialized Spaces and the Popular Geographical Imagination. Berkeley: University of California Press.

Pripp, O. (I998) Att vara sin egen: Om småföretagande bland invandrare-mönster, motiv och möten. Tumba: Mångkulturellt centrum.

Pripp, O. (2005) 'Den segregerande välviljan: Kultur som makt', Öhlander, M. (ed.) Bruket av kultur. Hur kultur används och görs socialt verksamt. Lund: Studentlitteratur.

Rabinow, P. and Rose, N. (2003) 'Introduction: Foucault Today', Rabinow, P. and Rose, N. (eds.) The Essential Foucault. New York: The New Press.

Rolfson, M. (n.d.) Metod PM för aktörer som arbetar med arbetssökande somalier. Available at: http://skane.iogt.se/files/201 2/I $2 /$ Metod-PM-ESF-Projekt.pdf [Accessed February 29 20I6].

Rose N. (I999a) Powers of Freedom: Reframing Political Thought. Cambridge: Cambridge University Press.

Rose, N. (I999b) Governing the Soul: The Shaping of the Private Self. Second edition. London: Free Association Books.

Rose, N. (I996) 'Governing “Advanced” Liberal Democracies', Barry, A., Osborne, T. and Rose, N. (eds.) Foucault and Political Reason: Liberalism, Neoliberalism and Rationalities of Government. Chicago: University of Chicago Press.

Rose, N., O’Malley, P. and Valverde, M. (2009) 'Governmentality', Legal Studies Research Paper. o9(94). Sydney: University of Sydney.

Said, E. (1979) Orientalism. New York: Vintage Books.

Sassen, S. (1999) Guests and Aliens. New York: The New Press.

Schierup, C-U., Hansen, P. and Castles, S. (2006) Migration, Citizenship and the European Welfare State: A European Dilemma. Oxford: Oxford University Press.

Schierup, C-U., Krifors, K. and Slavnic, Z. (2015) 'Social Exclusion', Dahlstedt. M. and Neergaard, A. (eds.) International Migration and Ethnic Relations: Critical Perspectives. New York: Routledge.

Schierup, C-U. and Ålund, A. (20I I) 'The End of Swedish Exceptionalism? Citizenship, Neoliberalism and the Politics of Exclusion', Race \& Class. 53(I): 45-64.

Schram, S.F. (2007) Welfare Discipline: Discourse, Governance and Globalization. Philadelphia: Temple University Press. 
Selling, J. (20I3) Svensk antiziganism: Fördomens kontinuitet och förändringens förutsättningar. Limhamn: Sekel Bokförlag.

Silverman, D. (2000) Doing Qualitative Research: A Practical Handbook. London: Sage.

Simons, L. and Masschelein, J. (2007) 'The Learning Society and Governmentality: An Introduction', Masschelein, J., Simons, M., Bröckling, U. and Pongratz, L. (eds.) The Learning Society from the Perspective of Governmentality. Oxford: Blackwell Publishing.

Skr. 2008/o9: 24 (2008) Egenmakt mot utanförskap: Regeringens strategi för integration.

Skr. 20I I/I2:56 (20I I) En samordnad och långsiktig strategi för romsk inkludering $20 \mathrm{I} 2-2032$.

Snajdr, E. (2007) 'Ethnicizing the Subject: Domestic Violence and the Politics of Primordialism in Kazakhstan', Journal of the Royal Anthropological Institute. I3(3): 603-620.

SOU 1956: 43. Zigenarfrågan. I954 års zigenarutredning.

SOU 2000: 3. Välfärd vid vägskäl: Utvecklingen under 1990-talet.

Kommittén Välfärdsbokslut.

SOU 20IO: 55. Romers rätt: En strategi för Romer i Sverige.

Standing, G. (20I I) The Precariat: The New Dangerous Class. London: Bloomsbury Academic.

Statistics Sweden (2016) Definitioner. Statistics Sweden. Available at: http://www.scb.se/sv_/Vara-tjanster/Regionala-statistikprodukter/ Fardiga-tabellpaket/Definitioner/\# [Accessed 29 February 2016].

Svanberg, I. and Tydén, M. (1992) Tusen àr av invandring: en svensk kulturhistoria. Stockholm: Gidlund.

Swedish ESF Council (2009) National Structural Fund Programme for Regional Competitiveness and Employment (ESF) 2007-2013. Swedish ESF Council.

Swedish ESF Council (2013) Socialfonden i siffror 2013: Projektens deltagare och nytta. Örebro: Apel.

Swedish ESF Council (2016a) Somalier startar företag. Swedish ESF Council. Available at: http://www.esf.se/sv/Resultat/Projektbanken/ Behallare-for-projekt/Sydsverige/Somalier-startar-foretag/ [Accessed 29 February 2016]. 
Swedish ESF Council (2016b) Nya utbildningsinsatser med och för romer. Swedish ESF Council. Available at: http://www.esf.se/sv/ Resultat/Projektbanken/Behallare-for-projekt/Stockholm/Nya-utbildningsinsatser-med-och-for-romer/ [Accessed 29 February 20I6]. Swedish ESF Council (20I6c) EU-flaggor och slogan. Swedish ESF Council. Available at: http://www.esf.se/en/Vara-fonder/Socialfonden-2007-2013/Offentligora-medfinansiering-fran-EU/EU-flaggoroch-slogan/ [Accessed 29 February 2016].

Swedish ESF Council (2016d) ESF in the EU. Swedish ESF Council. Available at: http://www.esf.se/sv/Sidhuvud/The-swedish-ESF-council/ESF-in-the-EU/ [Accessed 29 February 2016].

Tesfahuney, M. and Grip, L. (2007) 'Integrationism: Viljan till detsamma', Nordisk Sambällsgeografisk Tidskrift. 43: 6I-9I.

Thematic Group on Inclusion (20I2) Bakgrund. Linköping University. Available at: http://www.isv.liu.se/remeso/samverkan-och-uppdrag/ tia/om-tia?l=sv [Accessed 29 February 2016].

Thematic Group on Inclusion (2013) TIA - Integration $i$ arbetslivet. Linköping University. Available at: http://www.isv.liu.se/remeso/samverkan-och-uppdrag/tia?l=sv [Accessed 29 February 2016].

Thematic Network on Asylum and Integration (2016) Welcome to the National Thematic Network on Asylum \& Integration in Sweden. Thematic Network on Asylum and Integration. Available at: http:// www.temaasyl.se/Templates/StartPage.aspx?id=I3 [Accessed I9 February 2016].

Thörnquist, A. (20I I) Arbete och integration: ESF-projekt riktade till somalier och romer. Linköping: Linköping University.

Tuschling, A. and Engemann, C. (2007) 'From Education to Lifelong Learning: The Emerging Regime of Lifelong Learning in the European Union', Masschelein, J., Simons, M., Bröckling, U. and Pongratz, L. (eds.) The Learning Society From the Perspective of Governmentality. Oxford: Blackwell Publishing.

Ulmestig, R. (2007) På gränsen till fattigvård? En studie om arbetsmarknadspolitik och socialbidrag. Lund: Socialhögskolan, Lund University. 
van, Baar, H. (201 2 ) 'Socio-Economic Mobility and Neo-Liberal Governmentality in Post-Socialist Europe: Activation and Dehumanisation of the Roma', Journal of Ethnic and Migration Studies. $38(8)$ : I 289-I304.

Vesterberg, V. (2013) 'Ethnicized Un/employability: Problematized Others and the Shaping of Advanced Liberal Subjects', Ephemera. Theory \& politics in organization. I3 (4): 737-757.

Vesterberg, V. (2015) 'Learning to be Swedish: Governing Migrants in Labour Market Projects', Studies in continuing education. 37(3): 302-3 I6.

Vesterberg, V. (2016a) 'Exploring Misery Discourses: Problematized Roma in Labour Market Projects', European Journal for Research on Education and Learning for Adults. 7(I): 25-40.

Vesterberg, V. (forthcoming 2016b) 'Rationalities of Exclusionary Inclusion: Constructing Others while Combatting Social Exclusion', Neergaard, A., Schierup, C-U. and Ålund, A. (eds.) Reimagineering the nation. Frankfurt: Peter Lang.

Vij, R. (2007) 'Introduction', Vij, R. (ed.) Globalization and Welfare: A Critical Reader. Basingstoke: Palgrave Macmillan.

Vogel, J., Hjerm, M. and Johansson, S. (2002). Integration till svensk välfärd? Om invandrares välfärd på 9o-talet. Stockholm: Statistics Sweden (SCB).

Wallin, C. (2OI2) Utvärdering av ESF-projektet "Somalier startar företag - jobbsök”. Christer Wallin projekt AB. Available at: http:// www.esf.se/PageFiles/220 I245/Somalier_slutrapport\% 2ofinal2.pdf [Accessed 29 February 2016].

Walters, W. (2012) Governmentality: Critical Encounters. London: Routledge.

Walters, W. and Haahr. J.H. (2005) Governing Europe: Discourse, Governmentality and European Integration. London: Routledge.

Winther-Jörgensen, M. and Phillips, L. (2002) Discourse Analysis as Theory and Method. London: Sage.

Wright Nielsen, T. (2009) Viljen til att frigöre: En undersögelse af empowerment i praksis. Lund: Socialhögskolan, Lund University. 



\section{Articles}

The articles associated with this thesis have been removed for copyright reasons. For more details about these see:

http://urn.kb.se/resolve?urn=urn:nbn:se:liu:diva-127382 